\title{
Curcumin in Liver Diseases: A Systematic Review of the Cellular Mechanisms of Oxidative Stress and Clinical Perspective
}

\author{
Mohammad Hosein Farzaei ${ }^{1, *}$, Mahdi Zobeiri ${ }^{2}$, Fatemeh Parvizi ${ }^{1}$, Fardous F. El-Senduny ${ }^{3}$ (D), \\ Ilias Marmouzi 4 (D), Ericsson Coy-Barrera ${ }^{5}$ (D), Rozita Naseri ${ }^{2}$, Seyed Mohammad Nabavi ${ }^{6}$, \\ Roja Rahimi ${ }^{7}$ and Mohammad Abdollahi ${ }^{8, *}$ (i) \\ 1 Pharmaceutical Sciences Research Center, Kermanshah University of Medical Sciences, \\ Kermanshah 6734667149, Iran; parvizi_70@yahoo.com \\ 2 Internal Medicine Department, Imam Reza Hospital, Kermanshah University of Medical Sciences, \\ Kermanshah 6734667149, Iran; mehdizobeiri@yahoo.com (M.Z.); rnasseri.75@gmail.com (R.N.) \\ 3 Biochemistry division, Chemistry Department, Faculty of Science, Mansoura University, Mansoura 35516, \\ Egypt; biobotany@gmail.com \\ 4 Laboratory of Pharmacology and Toxicology Faculty of Medicine and Pharmacy, Mohammed V University \\ in Rabat, Rabat 10100, Morocco; ilias.marmouzi@gmail.com \\ 5 Bioorganic Chemistry Laboratory, Facultad de Ciencias Básicas y Aplicadas, Universidad Militar Nueva \\ Granada, Campus Nueva Granada, Cajicá 250247, Colombia; ericsson.coy@unimilitar.edu.co \\ 6 Applied Biotechnology Research Center, Baghyatollah University of Medical Sciences, Tehran 1435916471, \\ Iran; Nabavi208@gmail.com \\ 7 Department of Persian Pharmacy, School of Traditional Medicine, Tehran University of Medical Sciences, \\ Tehran 1416663361, Iran; rojarahimi@gmail.com \\ 8 Toxicology and Diseases Group, The Institute of Pharmaceutical Sciences (TIPS) and Department of \\ Toxicology and Pharmacology, Faculty of Pharmacy, Tehran University of Medical Sciences, \\ Tehran 1417614411, Iran \\ * Correspondences: mh.farzaei@gmail.com (M.H.F.); Mohammad@TUMS.Ac.Ir (M.A.)
}

Received: 28 May 2018; Accepted: 28 June 2018; Published: 1 July 2018

\begin{abstract}
Oxidative stress has been considered a key causing factor of liver damage induced by a variety of agents, including alcohol, drugs, viral infections, environmental pollutants and dietary components, which in turn results in progression of liver injury, non-alcoholic steatohepatitis, non-alcoholic liver disease, liver fibrosis and cirrhosis. During the past 30 years and even after the major progress in the liver disease management, millions of people worldwide still suffer from an acute or chronic liver condition. Curcumin is one of the most commonly used indigenous molecules endowed by various shielding functionalities that protects the liver. The aim of the present study is to comprehensively review pharmacological effects and molecular mechanisms, as well as clinical evidence, of curcumin as a lead compound in the prevention and treatment of oxidative associated liver diseases. For this purpose, electronic databases including "Scopus," "PubMed," "Science Direct" and "Cochrane library" were extensively searched with the keywords "curcumin or curcuminoids" and "hepatoprotective or hepatotoxicity or liver" along with "oxidative or oxidant." Results showed that curcumin exerts remarkable protective and therapeutic effects of oxidative associated liver diseases through various cellular and molecular mechanisms. Those mechanisms include suppressing the proinflammatory cytokines, lipid perodixation products, PI3K/Akt and hepatic stellate cells activation, as well as ameliorating cellular responses to oxidative stress such as the expression of Nrf2, SOD, CAT, GSH, GPx and GR. Taking together, curcumin itself acts as a free radical scavenger over the activity of different kinds of ROS via its phenolic, $\beta$-diketone and methoxy group. Further clinical studies are still needed in order to recognize the structure-activity relationships and molecular mechanisms of curcumin in oxidative associated liver diseases.
\end{abstract}


Keywords: curcumin; hepatotoxicity; liver diseases; oxidative stress; systematic review

\section{Introduction}

During the past 30 years and even after the major progress in the liver disease management, millions of people still suffer from an acute or chronic liver condition worldwide. Liver diseases affect more than $10 \%$ of the world population and its mortal end-stage generally follows cirrhosis and liver cancer [1]. Diverse etiologies characterize the disease to constitute about the fourth to the fifth cause of deaths worldwide. The Nonalcoholic Fatty Liver Disease (NAFLD) is the global leading cause of liver diseases with $40 \%$ frequently, followed by Hepatitis B virus (HBV), Hepatitis C virus (HCV) and harmful alcohol consumption, accounting for $30 \%, 15 \%$ and $11 \%$, respectively [1].

Chronic liver diseases are often accompanied by increased oxidative stress, irrespective of the cause of the liver dysfunction [2]. Oxidative stress (indicating excessive reactive oxygen species (ROS) levels and an oxidant and antioxidant imbalance) can lead to cellular degradation of proteins, lipids and DNA. Reactive oxygen species (ROS) participates in the liver fibrogenic response and contributes to ischemia/regeneration, necrosis and apoptosis. These modifications result in altered gene expression and progressive liver damage [2].

Natural products provide a repertory for discovery of new leads that can be used in treating different types of diseases such as cancer, inflammation and liver diseases. More than half of all pharmaceutical products have been discovered from natural compounds or their derivatives [3]. In the United States and Europe, approximately $65 \%$ of patients use herbal medicines against liver disease, due to their wide availability, low toxicity, pharmacological activity and chemical diversity and low side effects compared to synthetic drugs [4-8]. Curcumin is the main constituent of turmeric, the rhizome of Curcuma longa. It is widely used due to its therapeutic effectiveness and acceptable safety specification $[9,10]$. Curcumin possesses several biological activities such as anti-inflammatory [11,12], anticancer [13], antioxidant [14] and the ability to heal wounds [15]. From these facts, the aim of this review is to compile and discuss the effects of curcumin for the prevention and treatment of oxidative associated liver diseases as well as to highlight its molecular mechanism of action.

\section{Liver Disease: Pathophysiology and Epidemiology}

The vitality of the human liver is mainly associated with the impressive processes attributed to this part of the entrails. Its nomination was even regarded as a synonym of life [1]. In fact, multiple functionalities are attributed to this triangular organ extending across the abdominal cavity below the diaphragm [1]. Its metabolic and secretory capacities can cause hepatocellular death and eventually liver disease by involving a prominent exposure to alcohol, dietary components and viral infections [16]. Apparently, this organ is extremely vulnerable to numerous pathologies mainly associated with its great number of functions, structural organization, strategic localization and cell sensitivities. A number of mechanisms such as direct damage, stimulation of immune response against cells, formation of reactive intermediates, cytoskeletal damage, disruption of normal cell metabolism, triggering of apoptosis and hypoxia are involved in hepatocellular injury.

Hepatitis is an inflammatory process caused by drugs, alcohol and often by a virus. This is commonly known as hepatitis A, B, C, D and E. For instance, it is estimated that between 130 and 150 million patients suffer from HCV infection globally [1]. Chronic hepatitis therefore occurs when the injury persists for more than 6 months, resulting in raising aminotransferase levels or viral markers [17]. On the other hand, the abnormal accumulation of lipids in hepatic cells (5\% or more) is generally referred as steatosis. The macrovesicular steatosis generates the propitious environment of alcoholic and non-alcoholic steatohepatitis (ASH \& NASH) lesion development [18,19]. NASH is associated with hepatic steatosis and inflammation [17], however ASH and NASH are hardly distinguished on single-handed histological grounds [20]. Their pathophysiology includes hepatocellular damage 
most severe in (or restricted to) perivenular areas, inflammation and fibrosis. In this sense, the nomenclatures alcoholic fatty liver disease (AFLD) and NAFLD are used to demonstrate a wide range of alterations between uncomplicated steatosis and cirrhosis [21]. NAFLD is a chronic liver disease in non-abusively alcohol-drinking patients. It is highly associated with obesity, type-II diabetes mellitus and hyperlipidemia (high levels of triglycerides, low-density lipoprotein cholesterol, cholesterol and low level of high-density lipoprotein cholesterol) [22]. NAFLD treatment mainly depends on the severity. Regardless whether it is treated or not, NAFLD may progress to fibrosis and cirrhosis in specific population and the risk increases with aging, diabetes and obesity [23-25]. Current treatments rely on increasing insulin sensitivity (thiazolidinediones and metformin), slow-rate lowering body weight, reducing lipid level (gemfibrozil) and protecting hepatocytes (ursodeoxycholic acid, betaine, $N$-acetylcysteine, vitamin E). Thiazolidinediones (TZD) increases insulin sensitivity and lipid oxidation; preventing their accumulation in the liver [26,27]. Unfortunately, TZD has adverse side effects leading to edema and increases the body weight $[26,28]$. Therefore, there is a need for new strategies to control those liver diseases such as NAFLD, cirrhosis and even liver cancer $[29,30]$.

\section{Role of Oxidative Stress in Development of Liver Disease}

The pathogenesis of liver diseases integrates the oxidative stress processes and damages, including lipids, proteins and DNA alterations as well as modulation of functional signaling pathways. Oxidative stress is an imbalance between antioxidant capacity and the level of ROS in cells. ROS and reactive nitrogen species (RNS) are now being used to describe the free radicals derived from molecular oxygen and the oxidants derived from NO•, respectively [31,32]. Additionally, ROS can be produced by the endoplasmic reticulum in the liver via the cytochrome P450 enzymes at the macrophages and neutrophils levels [2]. One of the mechanisms leading to oxidative stress is the modulation of protein expression under $\mathrm{H}_{2} \mathrm{O}_{2}$ stress. This alteration exposes the liver to severe oxidative stress, resulting in hepatocyte apoptosis. Oxidative stress induced liver diseases can also cause brain impairment and kidney failure [33,34].

Many etiological factors were associated with liver disease and are highly productive of ROS. In fact, studies have demonstrated that ethanol can result in a significant rising of mitochondrial ROS levels in hepatocytes [35]. Ethanol oxidation involves at least three distinct enzymatic pathways [36]. Alcohol dehydrogenase (ADH) firstly oxidizes ethanol to acetaldehyde and the latter is then oxidized to acetate by aldehyde dehydrogenases (ALDH) in the mitochondria. The ethanol oxidation is also promoted by the microsomal ethanol oxidizing system (MEOS), the cytochrome P450 enzyme Cytochrome P450 2E1 (CYP2E1) and the catalase in peroxisomes. An excessive consumption of alcohol results in a higher metabolic activity which elevates ROS and liver injury [37].

On the other hand, drug hepatotoxicity is linked to ROS and RNS productions [38]. Actually, the intake of medication can induce oxidative stress via increase of cellular oxidants and lipid peroxidation and depletion of antioxidants in the liver. For instance, sulfasalazine reduces superoxide dismutase (SOD) but increases catalase (CAT) activity. Zoledronic acid results in significantly elevated malondialdehyde (MDA) and nitric oxide levels, whereas reduced glutathione (GSH) levels [39]. Even paracetamol also increases MDA, nitrite and nitrate in the liver and reduces total SOD and $\mathrm{Cu} / \mathrm{Zn}$-SOD activities. In addition to these factors, exposure to heavy metals, microcystin, radiation and temperature have also been shown to cause oxidative damage in liver $[40,41]$.

\section{Curcumin and Oxidative Stress}

Curcuma longa (turmeric) is a widely used spice, coloring agent and source of curcumin [42]. Derivatives from Curcuma longa L. are including, Curcumin, Ar-turmerone, Methylcurcumin, Demethoxy curcumin, Bisdemethoxy curcumin and Sodium curcuminate. Curcumin that is in the most important fraction of Curcuma longa L., is one of the most commonly used indigenous molecules endowed by various protective functionalities $[42,43]$. The pharmacokinetic (PK) studies of curcumin have consistently reported that the bioavailability of curcumin is relatively low due to its instability, 
poor solubility and absorption and its rapid metabolic elimination by reduction and conjugation in the presence of mild temperature and light. Similar to rodent studies, the poor bioavailability of curcumin in humans causes a primary barrier to achieve adequate plasma levels with favorable pharmacological effects [42,44]. Hence curcumin derivatives are of great interest in biomedical research [43].

This bright-yellow curcuminoid contains a variety of functional antioxidant groups, including the $\beta$-diketo group, carbon-carbon double bonds and phenyl rings. Curcumin can thus eliminate lipid radicals in the cell membrane and become a phenoxyl radical, so it is considered a very strong lipid-soluble antioxidant [45]. Furthermore, curcumin was found to inhibit lipid peroxidation and neutralize ROS (superoxide, peroxyl, hydroxyl radicals) [46] and RNS (nitric oxide and peroxynitrite) [47]. The protective effect of curcumin against oxidative stress was previously described in vitro and in vivo [48-51]. For instance, its biomembrane-protective effect against peroxidative damage was mainly linked to its ROS scavenging ability [52]. The hydrogen donor capacity was also associated with its phenolic and/or central methylenic groups. The enol form of curcumin was demonstrated to be significantly more stable than the diketo form. This study also suggested that the hydrogen atom abstraction takes place in the phenolic group [52-55]. However, the activity of the radical and the reaction medium influenced the relative contribution of the phenolic group and the central methylenic group to the antioxidant activity [52,56]. In addition, curcumin degradation products can also claim for its antioxidant activities. It can degrade under basic $\mathrm{pH}$ after $30 \mathrm{~min}$ into ferulic acid and vanillin [57]. In addition, curcumin exhibited chelating activity and is able to capture ferrous ion through its functional carbonyl groups [45].

\section{Study Design}

Electronic databases including "Scopus," "PubMed," "Science Direct" and "Cochrane library" were searched for cellular, animal or human studies with the keywords "curcumin or curcuminoids" and "hepatoprotective or hepatotoxicity or liver" in title/abstract, along with "oxidative or oxidant" in the whole text. References of the final articles were also reviewed for more relevant articles. Data were collected from the inception date until 2018 (up to January). Only English language papers were included. Results from primary systematic search were screened by two independent investigators. All published articles as well as abstracts presented at meetings were evaluated. From a total of 1436 results, 707 were excluded because of duplication, 219 for being reviews and 392 being irrelevant judged on the title and/or abstract. From the 112 primarily selected papers, 47 were excluded based on the full texts. Finally, 65 articles were included in this review. Figure 1 illustrates a flow diagram of study selection process. 


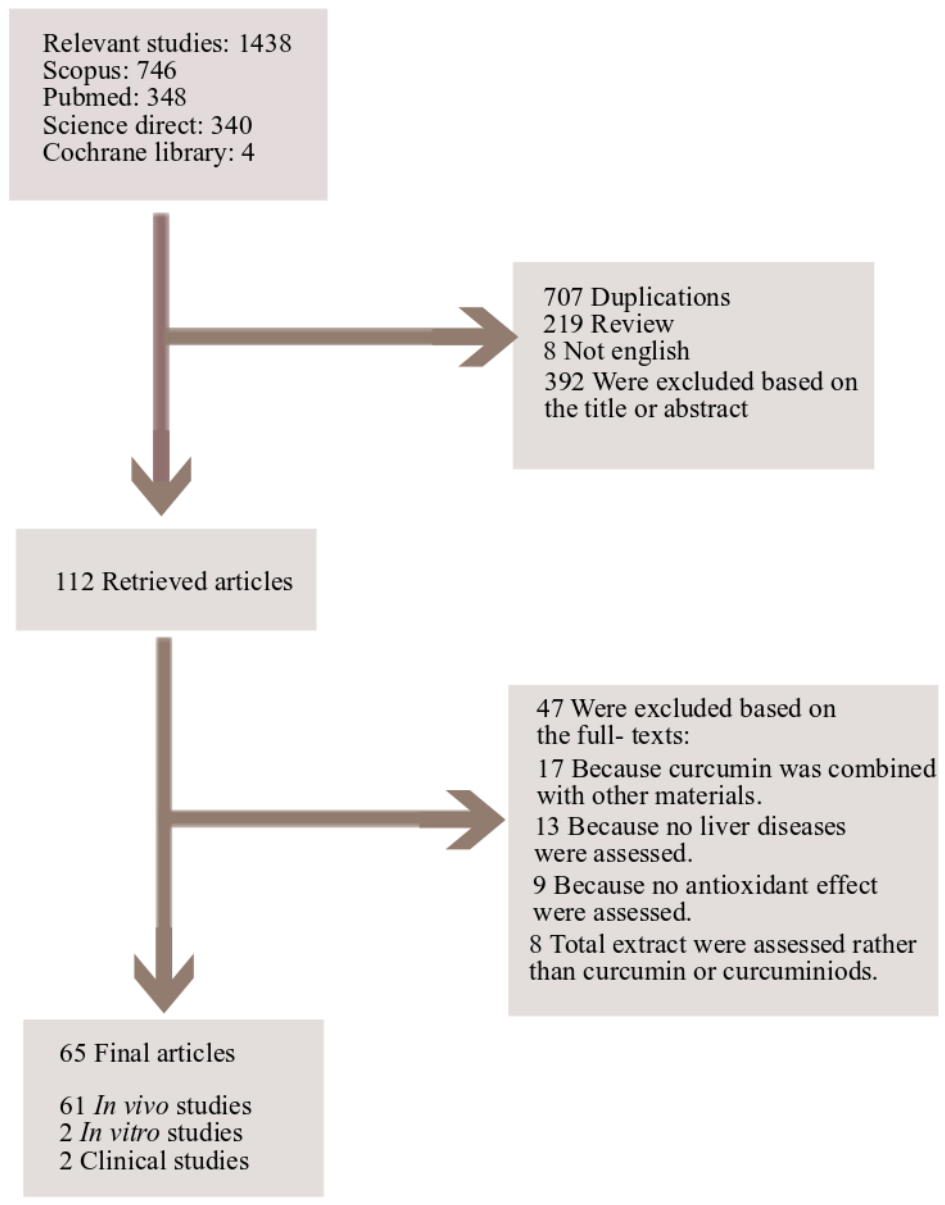

Figure 1. Study selection diagram.

\section{Cellular and Molecular Mechanisms of Curcumin in the Prevention of Oxidative Associated Liver Disease}

\subsection{Curcumin and Non-Alcoholic Steatohepatitis (NASH)}

The relationship between steatosis and fibrosis, hepatic cell injury and lobular inflammation is recognized as NASH. On this context, curcumin (200 mg/kg/day for 3 weeks) likewise exerted a protective effect on $\mathrm{CCl}_{4}$-induced NASH. During the respective histopathological inspection, depletions of lipid accumulation and MDA deposition were observed in male Wistar-Albino rats [58]. Curcumin also restricted successfully the fibrosis (both development and progression) in mice with methionine+choline-deficiency (MCD)-induced steatohepatitis [59]. Reductions of tissue inhibitor metalloproteinase-1 (TIMP-1) secretion and inhibition of 8-OH-deoxyguanosine-mediated hepatic oxidative stress in cultured stellate cells from mice were recorded [59]. In this regard, the hepatic inflammation and steatosis was then decreased along with the diminished levels of serum biochemical markers and cytokines and enlarged levels of liver antioxidants [60]. Furthermore, the nuclear factor erythroid 2 related factor 2 (Nrf2) protein expression was significantly higher in curcumin-treated rats, so authors concluded this NASH prevention/amelioration can be related with Nrf2 activation [60] as described for heavy metals-induced hepatotoxicity. A study was designed to investigate the underlying mechanisms of curcumin-treating protection on NASH progression using an innovative NASH-hepatocellular carcinoma (HCC) mouse model [61]. As result of this model, curcumin reduced the steatosis and fibrosis conditions and, as previously mentioned in several studies, caused a prominent decrease of biomarkers in NASH mice. However, the most important finding of this study 
was that curcumin can modulate/inhibit the high-mobility group box 1 (HMGB1)-NF-kB translocation to prevent the NASH progression and liver injury [61].

\subsection{Curcumin and Alcoholic Liver Disease (ALD)}

Morphological changes and clinical disorders in liver can be produced by the metabolism-related toxic effects of ethanol, since its oxidation affords apoptosis and cell injury-initiating products (e.g., acetaldehyde and ROS). These products can lead to fatty liver, hepatic inflammation, alcoholic hepatitis (necrosis) and progressive alcoholic cirrhosis (fibrosis). Aforementioned facts comprise the well-known alcoholic liver disease (ALD) [62]. Curcumin has been studied in several investigations for attenuating ALD effects and describing the respective mechanisms. Thus, inflammation and liver pathology can be improved in curcumin-administered ( 400 or $1200 \mathrm{mg} / \mathrm{kg} /$ day orally for 4 weeks) female Sprague-Dawley rats. Decreasing of hepatic MDA levels and inhibition of NF- $\mathrm{kB}$ activation were also observed for both doses but lower ones could avoid hepatocyte apoptosis [63]. Curcumin additionally modulated the antioxidant capacity, alcohol metabolic enzyme activity (i.e., CYP2E1 inhibition) and lipid metabolism (i.e., increasing activated protein kinase (AMPK) expression) after chronic alcohol intake-induced liver injury [64]. Curcumin was also related to hepatoprotection acting as a redox regulator and time/dose-dependent heme oxygenase-1 (HO-1) inducer against ethanol-induced oxidative injury in hepatocytes [65]. In balb/c mice, curcumin has been also suggested to defend liver from chronic-ethanol-induced damage. It also mitigated hepatohistopathological changes and lipid accumulation and amended levels of common biomarkers [66]. The attenuation of liver oxidative stress by curcumin has been described via induction/modulation of antioxidant signaling pathways such as Nrf2 activation and up-regulation of detoxifying genes expression (e.g., NQO1, HO-1 and GCLC) via ERK/p38-MAPK pathways [67]. Moreover, curcumin treatment $(150 \mathrm{mg} / \mathrm{kg} /$ day for 8 weeks) exhibited health benefits in female Wistar-Furth rats through lipid metabolism modulation. Curcumin treatment alleviated the hepatosteatosis and suppressed the atherogenesis in ALD, even enhancing the antiatherogenic markers, that is, PON1/HTLase and GSH [68].

However, despite the potential of curcumin as an anti-inflammatory and antifibrotic agent against liver damage, some concentration-dependent negative effects were reported in male C57BL/ 6 mice. Based on those findings, curcumin seems to have dual impacts on alcoholic liver injury. The recognized hepatoprotective effect of curcumin was achieved at $0.1 \mathrm{mM}$, whereas an acceleration of liver injury and cellular edema was observed using $1 \mathrm{mM}$ dose [69]. These facts can therefore be considered as a caution on using high doses of traditional medicines. In this sense, literature has a plethora of positive effects for more affordable therapeutics but negative ones are infrequently reported.

\subsection{Curcumin for the Prevention of the Oxidative Stress in Liver}

The imbalance between the generation and degradation of ROS can cause oxidative stress and eventually the generation of free radicals and cellular damage. However, as will be explained later, it has been reported that curcumin can be used for the prevention of oxidative stress in the liver. Some of the important mechanisms of curcumin in the prevention of oxidative associated liver disease are shown in Figure 2. Hydrogen peroxide was used by AL-Rubaei and colleagues as an agent that can damage liver cells. Their result showed that curcumin prevented liver toxicity and lower levels of alanine aminotransferase (ALT), aspartate aminotransferase (AST) and alkaline phosphatase (ALP) enzymes could be measured [70]. The effect of the pre- and post-treatment of curcumin were examined in rats contacted with methotrexate (MTX) induced oxidative stress. The results showed that the amelioration of antioxidant enzymes, including glutathione $S$-transferase (GST), glutathione reductase (GR), glutathione peroxidase (GPx), SOD and CAT, also the inhibition of ROS production can prevent oxidative stress in pre-treatment. Curcumin post-treatment can control the balance between oxidant and antioxidant [71]. In another work, the ability of curcumin was shown to treat hepatotoxicity caused by methotrexate [72]. AL-Harbi et al. found that administration of curcumin $(60 \mathrm{mg} / \mathrm{kg})$ have 
hepatoprotective effects on sodium fluoride induced oxidative stress. It can reduce hepatotoxicity and liver enzyme activities [73]. The effect of curcumin against oxidative stress induced by malathion (MAL), an organophosphorus insecticide (OPI), has been reported to reduce the MDA and nitric oxide (NO) levels and increased the GSH levels [74]. Excessive accumulation of iron overload (IOL) in the liver leads to oxidative stress as a result of cellular injury. The result of a study performed by Ali Hussein and colleagues indicated that treatment of rats with oxidative damage induced by IOL, significantly increased serum unsaturated iron binding capacity (UIBC), total protein, albumin, GSH, SOD and CAT activity accompanied by a reduction in serum iron, total iron-binding capacity (TIBC), transferrin (TF), ALT and AST activities, NO and MDA levels [75]. Similarly, in another study, the hepatoprotective effect of curcumin against oxidative stress created by IOL was confirmed [76]. Ciftci et al. in a rat model of oxidative stress induced by 2,3,7,8-tetrachlorodibenzo-p-dioxin (TCDD), a persistent environmental pollutant, noticed that the administration of $100 \mathrm{mg} / \mathrm{kg} /$ day curcumin reduced liver level of thiobarbituric acid reactive substances (TBARS). TCDD also increased liver levels of GSH, CuZn-SOD and GSH-Px [77]. Coneac et al. found that curcumin is able to reduce oxidative stress in acute experimental inflammation produced by Turpentine oil [78]. Dai et al. has confirmed that curcumin could ameliorate reduced L02 cell viability, prevent oxidative stress and inhibit the rises of SOD activity and GSH level. It could also be used as a prospective medical factor for quinocetone (QCT)-induced oxidative stress in human hepatocyte L02 cells [79]. In another in vitro study, the ability of curcumin to suppress oxidative stress in rat hepatic stellate cells (HSCs)-T6 was tested. Secretion of extracellular matrix (ECM) molecules and the levels of ROS and MDA were found to be decreased, whereas nuclear expression levels of Nrf2 and the levels of GSH were increased. Additionally, the expression of smooth muscle $\alpha$-actin ( $\alpha$-SMA) was suppressed [80]. It has been demonstrated that curcumin possesses the ability to attenuate lipid peroxidation and increase GSH level in rats exposed to cadmium, an industrial pollutant [81]. An increase of GSH level and SOD, GPx, GR and CAT activities and decrease of MDA level were also observed with curcumin in an immobilization-induced stress rat model, which changes the activities of antioxidant enzymes [82]. In carbon tetrachloride $\left(\mathrm{CCl}_{4}\right)$-induced liver injury and fibrogenesis model, it was demonstrated that curcumin could be effective in protecting the liver by reducing oxidative stress. Activity of NF- $\mathrm{kB}$, production of proinflammatory cytokines, structure of liver tissue and activation of HSC were then inhibited [83,84]. Singh et al. indicated that curcumin can be a potent protective agent against lindane as a pesticide that induces hepatotoxicity in rats. The presence of curcumin (pre- and post-treatment) with lindane significantly normalized the increased lipid peroxidation and decreased CAT, GPx, GR and SOD activities [85]. The possible protective role of curcumin was evaluated on cypermethrin-induced oxidative damage. A significant decrease in lipid peroxidation and the blood biochemical markers and decrease in CAT, GPx and GSH levels was observed in the liver of rats exposed to cypermethrin [86]. Watanab et al. determined the possibilities of curcumin in preventing or minimizing the oxidative stress induced by administration of trichloroethylene (TCE) in mouse liver. The activities of antioxidative enzymes were thus measured after curcumin protection [87].

\subsection{Curcumin and Liver Injury}

Curcumin and related phenolics have been associated with the inhibition of lipid peroxidation, free radical formation and DNA damage under the role of radical scavengers and/or antioxidants. However, additional examination has been suggested to be explored in order to elucidate the mechanisms for the beneficial properties of curcumin on several oxidative stress-associated diseases such as liver injury. Thus, protective effects of curcumin on liver injury induced by different factors have been described by several studies using murine models. Association with the HO-1, an important mediator of cytoprotective events, might be considered as a plausible explanation about the way curcumin can act. Hepatoprotection of curcumin (single dose at $100 \mathrm{mg} / \mathrm{kg}$ intra peritoneal) against lipopolysaccharide-induced hepatitis in D-galactosamine-sensitized rats was clearly connected with the HO-1 up-regulation and the consequently bilirubin production. This protective effect accordingly 
impacted on nitric oxide synthase 2 (NOS-2) down-regulation and reduced the amounts of NO and lipid peroxidation products in liver [88].<smiles>COc1ccc(/C=C/C(=O)/C=C/c2ccc(OC)c(O)c2)cc1O</smiles>

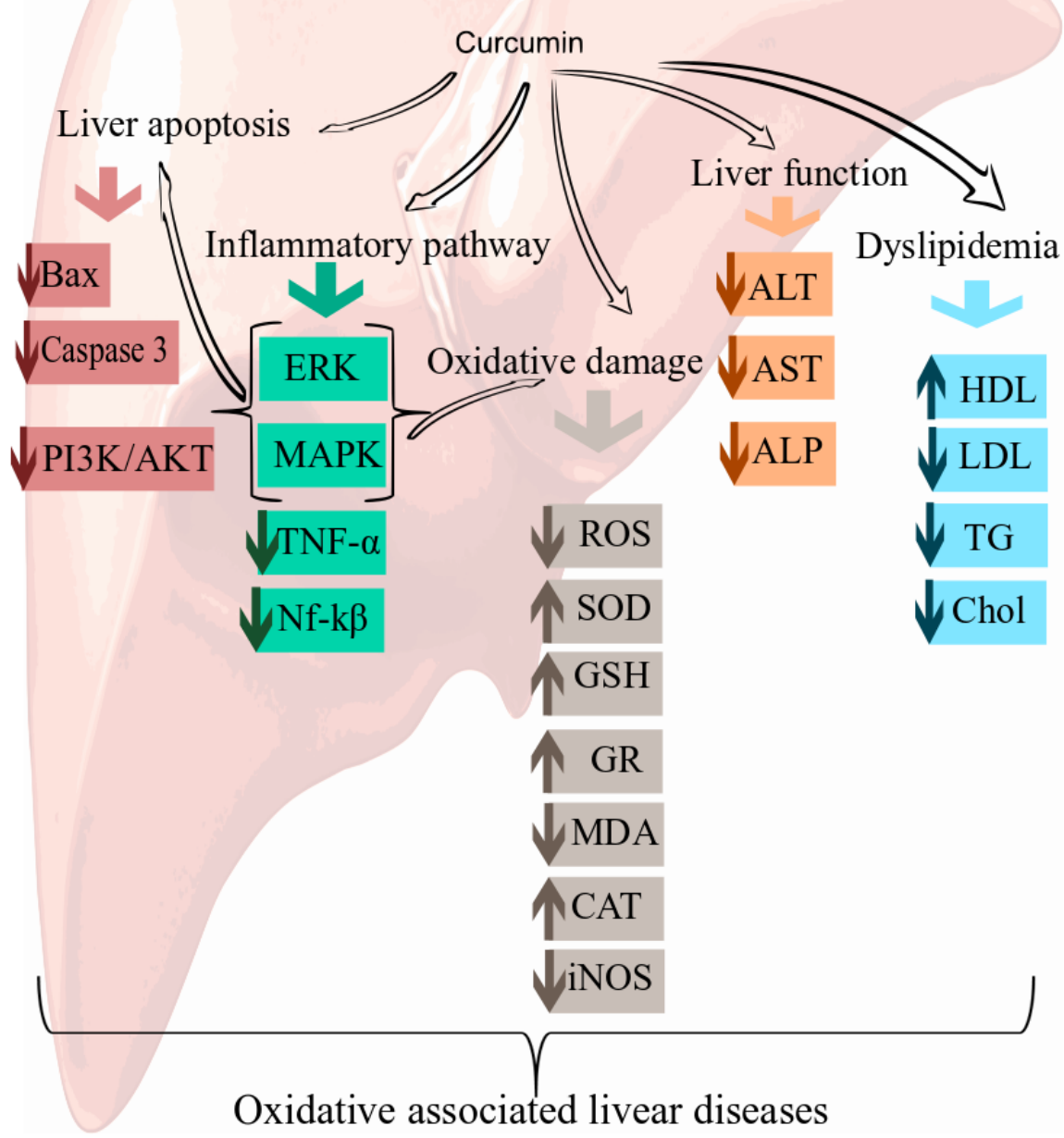

Figure 2. Cellular and molecular mechanisms of curcumin in the prevention of oxidative-associated liver disease. Alanine aminotransferase (ALT), aspartate aminotransferase (AST), alkaline phosphatase (ALP), reactive oxygen species (ROS), sulfasalazine reduces superoxide dismutase (SOD), glutathione (GSH), glutathione reductase (GR), malondialdehyde (MDA), catalase (CAT), inducible nitric oxide (iNOS), high-density lipoprotein (HDL), low-density lipoprotein (LDL), triglyceride (TG), extracellular signal-regulated kinases (ERK), mitogen-activated protein kinase (MAPK).

Relatedly, prophylactic administration of curcumin to mice ( $300 \mathrm{mg} / \mathrm{kg} /$ day orally for 7 days) resulted in a reasonable chemopreventive capacity for protection of microcystins-induced liver injury [89]. The statistically significant reduction of ALT, lactate dehydrogenase (LDH) and GST levels in comparison to that of a microcystins-treated group were additionally observed. Positive MDA and negative SOD variations were also detected, so the authors concluded that curcumin can improve the hepatic antioxidative abilities in mice [89]. Comparable kind of reduction in oxidative stress and DNA damage was furthermore observed in Wistar albino rats $(50 \mathrm{mg} / \mathrm{kg} /$ day orally for 14 days), since the biomarkers levels after biliary blocking were diminished in curcumin-treated rats. 
This result was a clear indication that curcumin assisted the recovery of liver function parameters, specifically on protecting the cholestasis-caused damages. In addition, curcumin generated a further reduction of ductal proliferation and portal inflammation in comparison with the induced group after histopathological evaluation. These facts indicated correspondingly a valuable decreasing of the inflammatory process. Similarly, after biliary duct ligation (BDL)-induced liver injury, curcumin promoted the statistically significant reduction of MDA, glutathione, NO and tumor necrosis factor- $\alpha$ (TNF- $\alpha$ ) levels and enhancing the catalase, SOD and GST activities in liver [90]. Another study in liver tissue of Wistar rats also evidenced that curcumin can exert protection on BDL-induced hepatic damage through antioxidant action [91]. The down-regulation of Rho-related C3 botulinum toxin substrate (Rac1), NADPH oxidase-1 (NOX1) and Rac1-guanosine triphosphate (Rac1-GTP) and enhanced levels of hepatic enzymes (i.e., ALP, AST, ALT) and antioxidants (i.e., thiols, SOD and catalase) were also identified [91]. Additionally, hepatoprotective effect against ischemia/reperfusion (I/R)-promoted liver injury was found upon curcumin pretreatment (100 mg/kg IP $30 \mathrm{~min}$ prior to I/R) in Female Wistar Albino rat. Thus, the reduction of some liver injury indexes in blood (i.e., NO, TNF- $\alpha$, methyl guabidine (MG), glutamic oxaloacetic transaminase (GOT), glutamate pyruvate transaminase (GPT) and $\mathrm{LDH}$ ) were also described as an indication of the potential of curcumin against inflammatory responses and oxidative/nitrosative stress during reperfusion liver injury [92].

Discrepancy between ineffective antioxidant defense and enlarged free radical production in liver has been evidently linked with drugs exposure-related oxidative stress [93]. In this sense, curcumin (three doses at $200 \mathrm{mg} / \mathrm{kg}$ during $36 \mathrm{~h}$ ) also triggered attenuated levels of biochemical parameters in liver damage induced by acetaminophen overdose toxicity (at $750 \mathrm{mg} / \mathrm{kg}$ orally) in albino western rats. Particularly, down-regulation of pro-apoptotic Bax and macrosialin cluster of differentiation 68 (CD68) protein expressions were observed through immunohistochemical evaluations [94]. The hepatoprotective results were increased whether curcumin was combined with thymoquinone, comprising fewer side effects in comparison to $N$-acetylcysteine (i.e., the best antidote for acetaminophen hepatotoxicity). Similar results were found on gentamicin-induced liver injury in male albino rats, since curcumin administration $(20 \mathrm{mg} / \mathrm{kg}$ /every other day, oral for 21 days) exhibited a statistically significant reduction of levels of biochemical parameters, TNF- $\alpha$ and bilirubin. Liver histological alterations and apoptotic executioner caspase-3, the proapopototic Bax and antiapoptotic B-cell lymphoma-2 (Bcl-2) protein expressions were successfully amended in curcumin-treated animals [95].

Several reports have also recognized the protective capacity of curcumin on liver injury produced by some xenobiotics. Curcumin (100 or $200 \mathrm{mg} / \mathrm{kg} /$ day intra peritoneal) has been previously described to exhibit a significant hepatoprotective activity against liver damages induced by aflatoxin B1 [96], lambda cyhalothrin [97], $\mathrm{CCl}_{4}$ [98,99], mercury [100] and other heavy metals [101] in adult rats. Levels of lipid peroxidation, serum biomarker enzymes, liver MDA, hydroxyproline and liver antioxidants (i.e., GSH, SOD, catalase) were correspondingly modified after curcumin treatment. DNA fragmentation preventing and mitochondrial functionalities preserving were also explained according to those findings.

Regarding protective ability of curcumin against heavy-metals (such as copper, cadmium, chromium, mercury, lead and arsenic), its free radical scavenging/reducing power/chelating capacities can restrain the heavy-metals-promoted hepatotoxicity by liver oxidative stress-related antagonism. These abilities were connected with the induction of the Nrf2/antioxidant response elements/Kelch-like ECH associated protein 1 (Nrf2/ARE/Keap1) pathway [100,101]. On the other hand, curcumin also exhibited a dose-dependent protection in $\mathrm{CCl}_{4}$-induced liver damage of Jian carp (Cyprinus carpio var. Jian). The up-regulation of the common antioxidative activities (SOD and GSH) and inhibition of cytokine production (e.g., Interleukin-1 $\beta$ (IL-1 $\beta$ ), TNF- $\alpha$, Interleukin 12 (IL-12)) were then observed and consequently correlated to the exhibited protective effect [102].

Despite the enormous, evidenced potential of curcumin to impede liver injury, the investigations are still quite scarce. The related studies are limited to evaluate the blood and liver levels of some 
biomarkers and examine liver histopathological/immunohistochemical results. Further studies on molecular, cellular and physiological mechanisms during curcumin hepatoprotection are accordingly needed prior a claim as a potential therapeutic agent against several oxidative stress-associated liver injuries.

\subsection{Curcumin and Hepatotoxicity}

In terms of drug toxicity, the liver is often the targeted organ. More than 1000 drugs can cause toxicity in the liver and subsequently induce oxidative stress, steatosis and cell death. Most of anti-cancer, anti-analgesic and anti-inflammation drugs and antidepressants can be hepatotoxic. The production of ROS and RNS as the primary events, mitochondrial dysfunction and lipid dysmetabolism as the principal mechanisms of drug toxicity can be mentioned [103,104]. The main problem with these medications is the usage of high doses, which usually lead to hepatotoxicity in humans and experimental animals. Paracetamol (acetaminophen), commonly used as an antipyretic, is one of the most widespread drug-induced liver damage [105]. Manal et al. showed that curcumin supplementation at doses of 50 and $100 \mathrm{mg} / \mathrm{kg} /$ day to experimental rabbits with paracetamol-induced hepatotoxicity lowers the elevated aspartate transaminase, alkaline phosphatase and alanine transaminase levels and raises the total protein and albumin levels in plasma. In addition to these changes, curcumin increased the levels of red blood cells and platelets [105]. In another study, the efficacy of curcumin to manipulate the protein content, Succinate dehydrogenase (SDH), TBARS, Adenosine triphosphatase activity (ATPase), alkaline phosphatase activity (ALKase), acid phosphatase activity (ACPase), SOD and body weight of chloroquine phosphate (CQ)-induced hepatotoxicity was observed in a rat model [106]. Propanil (3,4-dichloropropioanilide), used to control weeds in wheat and rice products, is one of the most high-risking herbicide for humans. In a rat model of propanil-induced hepatotoxicity, curcumin improved the effects of propanil intoxication by decreasing lipid peroxidation levels and restored the levels of serum enzymes and reduced glutathione [107]. Although the liver has a high metabolic capacity, it is susceptible from a number of toxins such as thioacetamide (TAA) that causes the rise of ROS levels and the activation of HSCs [104]. Fazal et al. contributed to a study showing the protective effects of curcumin on liver toxicity in a rat TAA model by suppressing oxidative stress and angiotensin-converting enzyme (ACE) gene expression, protecting the liver tissue and anti-oxidant enzymes and restoring hepatocytes [108]. Additionally, Shapiro et al. confirmed the hepatoprotective effect of curcumin by reporting decreased levels of TBARS, minimized oxidative stress and inhibited inducible nitric oxide (iNOS) protein and NF- $\mathrm{KB}$ in acute thioacetamide hepatotoxicity rats supplemented with 200 and $400 \mathrm{mg} / \mathrm{kg}$ per day curcumin [109]. The increased production of reactive oxygen intermediates and lipid peroxidation, migration of activated PMNs into the liver, severe oxidative stress and eventually extensive damage to the liver are induced by lipopolysaccharides (LPS). Kaur et al. studied the effect of treatment of hepatotoxicity induced by LPS on enzymes and oxidative stress in rat liver. The results showed that the levels of ALT, AST and ALP as well as bilirubin in serum were significantly decreased, while the cytotoxic effects of NO, oxygen free radicals and cytokines were remarkably prevented [110]. Due to the accumulation of nanoparticles in different organs of experimental animals, including liver, spleen, brain and so forth, administration of $\mathrm{NZnO}$ (50 mg/kg/day) and treatment with curcumin (200 mg/kg/day) were measured in rats exposed to hepatotoxicity. The increased serum ALT, AST and ALP activity and MDA, decreased GPx and SOD levels suggests a link between NZnO and hepatic oxidative stress [111]. Although sodium fluoride is a substance that induces toxicity and oxidative stress, Moghaddam et al. showed that the protective effect of curcumin was related to its ability to adjust the imbalance of antioxidant enzymes and reduced lipid peroxidation levels in rat with fluoride-induced hepatotoxicity [112]. 60-70\% of synthetic dyes are azo dyes that are soluble in processed food. It causes environmental contamination during food processing and can thus have harmful effects on human lymphocytes through direct interaction with genetic material such as DNA [113]. It has been reported that the azo dye tartrazine $(\mathrm{Tz})$ can cause pathological changes in the liver and kidneys. EL-Desoky and colleagues administered 
doses of 1.0, 2.0, or $4.0 \mathrm{~g}$ of curcumin to a rat model of Tz-mediated hepatotoxicity and oxidative stress. They noticed that maximum improving effects on antioxidant enzyme activities were observed when $2.0 \mathrm{~g}$ of curcumin was used compared to those exposed to Tz alone [101]. Random or intentional intake of high doses of $\mathrm{Cr}$ compounds, such as potassium dichromate $\left(\mathrm{K}_{2} \mathrm{Cr}_{2} \mathrm{O}_{7}\right)$, can lead to serious damage to the liver. This damage is generated by increasing lipid peroxidation and ROS levels and inhibiting structural tissue injury, antioxidant enzymes and mitochondrial damage [114,115]. García-Niño et al., in a model of liver oxidative stress induced by $\mathrm{K}_{2} \mathrm{Cr}_{2} \mathrm{O}_{7}$, remarked that $400 \mathrm{mg} / \mathrm{kg}$ curcumin could prevent the increased activities of plasma enzymes, while $15 \mathrm{mg} / \mathrm{kg} \mathrm{K}_{2} \mathrm{Cr}_{2} \mathrm{O}_{7}$ is unable to induce alterations in the oxidative stress markers [115]. Similarly, the protective effect of curcumin (400 mg/kg) was evaluated by García-Niño and colleagues on the hepatotoxicity provoked by $\mathrm{K}_{2} \mathrm{Cr}_{2} \mathrm{O}_{7}$ $(15 \mathrm{mg} / \mathrm{kg})$ in rats. Prevention of histological damage, decrease in body weight gain, increase of liver weight, liver/body ratio and amelioration of the liver oxidative damage can be mentioned as their result [114].

\subsection{Curcumin and Liver Fibrosis and Cirrhosis}

If the development of liver disease is not prevented, it can progress from simple steatosis to more severe disease forms, including hepatitis, fibrosis and cirrhosis [103]. Collagens are the most abundant protein in the extracellular matrix and HSCs are the main cells that produce collagen in the liver. Fibrosis is characterized by an excessive deposition of collagen between hepatocytes and sinusoids [104,116]. Chronic tissue injury, ROS, inflammatory cytokines and apoptotic signals activate the HSC [104,116]. Transforming growth factor beta (TGF- $\beta$ ) also has a critical role in initiating and the development of the HSC phenotypic activity [117]. In addition, oxidative stress increasingly activates HSCs [118]. If the imbalance between synthesis and destruction of collagen by membrane-bound metalloproteinase continues, the fibrosis advances to become cirrhosis. Cirrhosis is the end-stage of progressive fibrosis and is characterized by the degradation of the hepatic lobules structures and blood flow failure $[104,117]$. $\mathrm{CCl}_{4}$ is one of the causative of liver damage, developing fibrosis and further cirrhosis. $\mathrm{CCl}_{4}$ initiates cell damage by producing free radicals and increasing collagen synthesis through lipid peroxidation mechanism. Hence, the efficacy of curcumin has been examined in hepatic fibrosis induced by $\mathrm{CCl}_{4}$ in rats. It was concluded that treatment with curcumin significantly reduced serum and tissue cholesterol profiles, GOT, GPT, ALP and TBARS [119]. Bruck et al. showed that curcumin inhibited the thioacetamide-induced cirrhosis in rats. They also found a decreasing of oxidative stress, hydroxyproline levels, liver histopathology and spleen weights $(p<0.001)$ [117]. Chenari et al. established that treatment with curcumin in the BDL fibrotic rat model significantly reduced low-density lipoprotein (LDL), total cholesterol (TC) and triglyceride (TG) levels, AMPK, carnitine palmitoyltransferase 1A (CPT-1A), isocitrate dehydrogenase 2 (IDH2) and manganese-dependent superoxide dismutase (MnSOD) gene expressions. In addition, it was observed that the level of HDL and protein/gene expression of the silent mating type information regulation type 2 , homolog3 (SIRT3) in response to oxidative stress, by reducing ROS level, significantly increased [118]. Curcumin can also be effective in the treatment of chronic hepatic diseases and reducing levels of ALT, $\gamma$-GTP, TGF- $\beta$ expression can be measured in a rat model of BDL-induced liver cirrhosis. $100 \mathrm{mg} / \mathrm{kg}$ of curcumin was also capable of decreasing oxidative stress by alterations of glutathione levels [117]. In another study, the effectiveness of curcumin in the treatment of BDL was shown by reducing liver damage and oxidative stress [120]. There is a work performed on a mouse model of LPS-induced acute liver injury by Zhong and colleagues who studied the hepatoprotective role of curcumin. This effect was then demonstrated through reduction of pro-inflammatory cytokines and oxidative stress, increase of liver antioxidant enzymes and decrease of liver apoptosis by inhibiting phosphoinositide 3-kinase/protein kinase B (PI3K/AKT) signaling pathway [121]. Preclinical studies evaluating the effects of curcumin in the prevention/accelerating of oxidative associated liver diseases are listed in Table 1. 
Table 1. Preclinical studies evaluating the effects of curcumin in the prevention/accelerating of oxidative associated liver diseases.

\begin{tabular}{|c|c|c|c|c|c|}
\hline Liver Disease Type & $\begin{array}{c}\text { Experimental Model Used } \\
\text { (Animal, Strain, Genetic or } \\
\text { Dietary Liver Injury) }\end{array}$ & Curcumin Source & Dose and Formulation (Injection) & Duration of Treatment & Reference \\
\hline \multicolumn{6}{|c|}{ Non-Alcoholic Steatohepatitis (NASH) } \\
\hline $\begin{array}{c}\mathrm{Ccl}_{4} 0.5 \mathrm{~mL} / \mathrm{kg} / \text { every other } \\
\text { day } / \mathrm{SC} / 3 \text { weeks }\end{array}$ & Male Albino Wistar rat & Sigma, St. Louis, MO, USA & $200 \mathrm{mg} / \mathrm{kg} /$ day in olive oil (oral) & 3 weeks & [58] \\
\hline $\begin{array}{l}\text { Methionine and choline deficient } \\
\text { diet (MCD diet) }\end{array}$ & Male C57BL/ 6 mice & Sigma, St. Louis, MO, USA & $\begin{array}{l}25 \mu \mathrm{g} / \text { every other day/in DMSO } \\
\text { (IP) }\end{array}$ & 4,8 or 10 days & [59] \\
\hline High fat diet (HFD) & Adult Sprague-Dawley rats & Sigma, St. Louis, MO, USA & $\begin{array}{c}50 \mathrm{mg} / \mathrm{kg} / \text { day } / \text { suspended in } 0.5 \% \\
\text { CMC }\end{array}$ & 6 weeks & {$[60]$} \\
\hline $\begin{array}{c}200 \mu \mathrm{g} \mathrm{STZ/single} \mathrm{dose/SC} \mathrm{/} 2 \text { days } \\
\text { after birth } \\
\text { (HFD 32) }\end{array}$ & C57BL/ $6 \mathrm{~J}$ mice & Sigma-Aldrich, Tokyo, Japan & $\begin{array}{c}100 \mathrm{mg} / \mathrm{kg} / \text { day in } 1 \% \text { gum Arabic } \\
\text { (oral) }\end{array}$ & 14 weeks & [61] \\
\hline \multicolumn{6}{|c|}{ Alcoholic Liver Disease } \\
\hline $\begin{array}{c}50 \% \text { ethanol }(7.5 \mathrm{~g} / \mathrm{kg} / \mathrm{day} / 4 \\
\text { weeks } / \text { oral })\end{array}$ & Female Sprague-Dawley rats & Cayman Chemical Company, USA & $\begin{array}{c}400 \text { or } 600 \mathrm{mg} / \mathrm{kg} / \text { twice a day } / \text { in } \\
50 \% \text { ethanol }\end{array}$ & 4 weeks & [63] \\
\hline $\begin{array}{c}25 \% \text { ethanol }(5 \mathrm{~g} / \mathrm{kg} / \text { day } / 6 \\
\text { weeks } / \text { oral })\end{array}$ & Male ICR mice & Sigma, St. Louis, MO, USA & 19.7 or $47.5 \mathrm{mg} / \mathrm{kg} /$ day (oral) & 6 weeks & [64] \\
\hline $100 \mathrm{~mm}$ ethanol for $8 \mathrm{~h}$ & $\begin{array}{l}\text { Primary rat hepatocytes from } \\
\text { male Sprague-Dawley rats }\end{array}$ & $\begin{array}{c}\text { diferuloylmethane; CAS No. } \\
\text { 458-37-7, Sigma, St. Louis, MO, } \\
\text { USA }\end{array}$ & $\begin{array}{c}5-50 \mathrm{M} / \text { dissolved in } 0.5 \mathrm{~N} \mathrm{NaOH} \\
\text { then diluted in PBS }\end{array}$ & $0-5 \mathrm{~h}$ before ethanol treatment & [65] \\
\hline $\begin{array}{c}2.4 \mathrm{~g} / \mathrm{kg} / \text { day ethanol for the initial } \\
4 \text { weeks and } 4 \mathrm{~g} / \mathrm{kg} / \text { day for } \\
\text { another } 2 \text { weeks }\end{array}$ & Male Balb/c mice & $\begin{array}{l}\text { Diferuloylmethane; CAS No. } \\
\text { 458-37-7), Sigma, St. Louis, MO, } \\
\text { USA }\end{array}$ & $75 \mathrm{mg} / \mathrm{kg} /$ day $/$ in DMSO (oral) & 6 weeks along with ethanol intake & {$[66]$} \\
\hline $\begin{array}{c}2.4 \mathrm{~g} / \mathrm{kg} / \text { day ethanol } / \text { daily } / 6 \\
\text { weeks }\end{array}$ & Adult Male Balb/C mice & $\begin{array}{l}\text { Purity }>98.0 \% \text {, from the National } \\
\text { Institute for Food and Drug } \\
\text { Control (Beijing, China) }\end{array}$ & 75 or $150 \mathrm{mg} / \mathrm{kg} /$ in olive oil/(oral) & $\begin{array}{l}1 \mathrm{~h} \text { before ethanol administration } \\
\text { for } 6\end{array}$ & [67] \\
\hline $\begin{array}{l}\text { Low } \omega-3 \text { poly unsaturated fatty } \\
\text { acids (PUFA) diet + ethanol } \\
\text { High } \omega-3 \text { PUFA + ethanol }\end{array}$ & Female Wistar-Furth rats & - & $150 \mathrm{mg} / \mathrm{kg} /$ day & 8 weeks & [68] \\
\hline $\begin{array}{c}5 \% \text { ethanol } / \mathrm{IV}, 5 \text { times a week } / 100 \\
\mu \mathrm{L} / \mathrm{mouse} / \text { for } 2 \text { weeks }\end{array}$ & Male C57BL/ 6 mice & Sigma-Aldrich, USA & $\begin{array}{c}1 \mathrm{mM} \text { or } 1 \mathrm{mM} / 100 \mu \mathrm{L} / \text { mouse }(\mathrm{IV}) \\
\text { dissolved in } 0.5 \mathrm{~N} \mathrm{NaOH} \text { then } \\
\text { diluted in PBS }\end{array}$ & 5 times a week for 2 weeks & [69] \\
\hline
\end{tabular}


Table 1. Cont

\begin{tabular}{|c|c|c|c|c|c|}
\hline Liver Disease Type & $\begin{array}{l}\text { Experimental Model Used } \\
\text { (Animal, Strain, Genetic or } \\
\text { Dietary Liver Injury) }\end{array}$ & Curcumin Source & Dose and Formulation (Injection) & Duration of Treatment & Reference \\
\hline \multicolumn{6}{|c|}{ Oxidative Stress Inducers } \\
\hline $\mathrm{H}_{2} \mathrm{O}_{2} 0.5 \%(v / v) /$ day / for 60 days & Male Wistar rats & $\begin{array}{l}\text { Crude curcumin was purchased } \\
\text { from local wet market in Baghdad, } \\
\text { Iraq }\end{array}$ & $200 \mathrm{mg} / \mathrm{kg} /$ day & $\begin{array}{l}\text { 1st model }=30 \text { days after induction } \\
\text { of oxidative stress } \\
\text { 2nd model }=15 \text { days then followed } \\
\text { by receiving } \mathrm{H}_{2} \mathrm{O}_{2} \text { for } 60 \text { days }\end{array}$ & [70] \\
\hline $\begin{array}{c}\text { Methotrexate } 20 \mathrm{mg} / \mathrm{kg} / \mathrm{I} . \mathrm{P} . / \text { single } \\
\text { dose }\end{array}$ & Rat & & 100 mg/kg/day (I.P.) & 5 days & [72] \\
\hline Melathion (MAL) $200 \mathrm{mg} / \mathrm{kg} /$ oral & Female Sprague Dawley rats & $\begin{array}{l}\text { Curcuma longa Turmeric, Sigma, St. } \\
\text { Louis, MO, USA (C1386) }\end{array}$ & $1 \mathrm{~g} / \mathrm{kg}$ (oral) & 1 days & [76] \\
\hline $\begin{array}{c}\text { Iron overload }\left(\text { Haemojet }{ }^{\circledR}\right) \\
\text { containing ferric hydroxide } \\
\text { polymaltose } \\
100 \mathrm{mg} / \mathrm{Kg} / \mathrm{I} . \mathrm{P} . / 3 \text { doses per } \\
\text { week/for } 2 \text { weeks }\end{array}$ & Male albino rats & $\begin{array}{l}\text { Purity } 95 \% \text {, Indian production, } \\
\text { purchased from El-Goumhoria Co., } \\
\text { Cairo-Egypt }\end{array}$ & $\begin{array}{c}100 \mathrm{mg} / \mathrm{kg} / \text { day } / \text { dissolved in } \\
\text { DMSO }\end{array}$ & 3,4 or 5 weeks & [75] \\
\hline $\begin{array}{c}\text { 2,3,7,8-tetrachlorodibenzo-p-dioxin } \\
2 \mathrm{mg} / \mathrm{kg} / \text { week/oral diluted in } \\
\text { corn oil }\end{array}$ & Female Sprague Dawley rats & $\begin{array}{c}\text { Sigma Chemical Co., St. Louis, } \\
\text { Missouri, USA }\end{array}$ & $\begin{array}{c}100 \mathrm{mg} / \mathrm{kg} / \text { day } / \text { dissolved in corn } \\
\text { oil }\end{array}$ & 30 and 60 days & [77] \\
\hline Turpentine oil 0.6 mL/kg/I.M. & Wistar Bratislava albino rats & $\begin{array}{c}\text { Purity }>98 \% \text {, Abcam (Cambridge, } \\
\text { United Kingdom) }\end{array}$ & $\begin{array}{c}150 \mathrm{mg} / \mathrm{kg} / \text { dissolved in } 0.5 \% \\
\text { CMC (oral) }\end{array}$ & $\begin{array}{l}\text { 1st model }=60 \text { min prior } \\
\text { Turpentine injection } \\
\text { 2nd model }=120 \mathrm{~min} \text { after } \\
\text { Turpentine injection }\end{array}$ & [78] \\
\hline $\begin{array}{c}\mathrm{Cdcl}_{2} 0.025 \mathrm{mmol} / \mathrm{kg} \text { to rats and } \\
0.03 \mathrm{mmol} / \mathrm{kg} \text { to mice } / \mathrm{S} \text {.C. }\end{array}$ & $\begin{array}{l}\text { Adult male Wistar rats and } \\
\text { male CD mice }\end{array}$ & $\begin{array}{c}\text { Sigma-Aldrich, St. Louis, MO, } \\
\text { USA }\end{array}$ & $\begin{array}{l}50 \mathrm{mg} / \mathrm{kg} / \text { day } / \text { dispersed in } 0.25 \% \\
\text { methylcellulose }\end{array}$ & 3 days & [81] \\
\hline $\begin{array}{l}\text { Immobilization-induced stress, rats } \\
\text { kept in the restrainers for } 1 \mathrm{~h} \text { every } \\
\text { day, for } 21 \text { consecutive days }\end{array}$ & Wistar albino rats & $\begin{array}{c}\text { Sigma-Aldrich Chemical (St. Louis, } \\
\text { USA) }\end{array}$ & 10 or 20 or $30 \mathrm{mg} / \mathrm{kg} /$ day $/ \mathrm{IP}$ & 21 days & [82] \\
\hline $\begin{array}{c}\mathrm{Ccl}_{4} 1 \mathrm{~mL} / \mathrm{kg}(1: 1) \text { in olive } \\
\text { oil/every other day for } 8 \\
\text { weeks./I.P. }\end{array}$ & Male Sprague-Dawley rats & - & $\begin{array}{c}200 \text { or } 400 \mathrm{mg} / \mathrm{kg} / \text { suspended in } \\
\text { PBS }\end{array}$ & $48 \mathrm{~h}$ & {$[83,84]$} \\
\hline $\begin{array}{c}\text { Lindane } \\
\text { 1st model }=60 \mathrm{mg} / \mathrm{kg} / \text { for } 24 \\
\mathrm{~h} / \mathrm{oral} \\
\text { 2nd model }=30 \mathrm{mg} / \mathrm{kg} / \text { for } 14 \mathrm{~d}\end{array}$ & Male Wistar rats & $\begin{array}{c}\text { Sigma Aldrich (St. Louis, MO, } \\
\text { USA) }\end{array}$ & $\begin{array}{c}100 \text { or } 200 \mathrm{mg} / \mathrm{kg} / \text { day } / \text { dissolved } \\
\text { in DMSO (oral) }\end{array}$ & $\begin{aligned} 1 \text { st } \text { model }= & \text { pretreatment for } 14 \\
& \text { days } \\
2 \text { nd model }= & \text { posttreatment for } 14 \\
& \text { days }\end{aligned}$ & [85] \\
\hline $\begin{array}{l}\text { Cypermethrin } 25 \mathrm{mg} / \mathrm{kg} / \text { day } / \text { for } \\
28 \text { days }\end{array}$ & Adult male Wistar rats & $\begin{array}{l}\text { Sigma Chemicals, USA and SRL } \\
\text { Chemicals, India. }\end{array}$ & $100 \mathrm{mg} / \mathrm{kg}$ (oral) & 28 days & [86] \\
\hline
\end{tabular}


Table 1. Cont.

\begin{tabular}{|c|c|c|c|c|c|}
\hline Liver Disease Type & $\begin{array}{l}\text { Experimental Model Used } \\
\text { (Animal, Strain, Genetic or } \\
\text { Dietary Liver Injury) }\end{array}$ & Curcumin Source & Dose and Formulation (Injection) & Duration of Treatment & Reference \\
\hline $\begin{array}{c}\text { Trichloroethylene (TCE) } 1.2 \\
\mathrm{mmol} / \mathrm{kg} / \text { diluted in corn oil } / 24 \mathrm{~h}\end{array}$ & Male ddY mice & - & $\begin{array}{c}10,50 \text { or } 100 \mu \mathrm{M} / \text { dissolved in } \\
\text { DMSO (I.P.) }\end{array}$ & $24 \mathrm{~h}$ & [87] \\
\hline \multicolumn{6}{|c|}{ In Vitro Study } \\
\hline Quinocetone (QCT)- & Human hepatocyte L02 cells & $\begin{array}{l}\text { Purity 98\%, Aladdin Reagent Co., } \\
\text { Ltd. (Shanghai, China) }\end{array}$ & 2.5 or $5 \mathrm{mM} / 0.1 \%$ DMSO & $\begin{array}{c}2 \mathrm{~h} \text { pretreatment then incubated for } \\
4 \text { or } 24 \mathrm{~h} \text { with QCT }\end{array}$ & [79] \\
\hline $\begin{array}{c}\text { Glucose oxidase (GO) } 100 \\
\mathrm{mu} / \mathrm{mL} / 2 \mathrm{~h}\end{array}$ & Rat HSCs-6 & $\begin{array}{c}\text { Sigma-Aldrich (St. Louis, MO, } \\
\text { USA) }\end{array}$ & $0.15 \mu \mathrm{M}$ & $\begin{array}{l}3 \mathrm{~h} \text { pretreatment then incubated } \\
\text { with GO for } 2 \mathrm{~h}\end{array}$ & [80] \\
\hline \multicolumn{6}{|c|}{ Liver Injury } \\
\hline $\begin{array}{c}\text { LPS (10 } \\
\mu \mathrm{g} / \mathrm{kg} / \mathrm{I.P.}) / \mathrm{D} \text {-galactosamine (400 } \\
\mathrm{mg} / \mathrm{kg} / \mathrm{I} . \mathrm{P} .) / 24 \mathrm{~h}\end{array}$ & Male Wistar rats & $\begin{array}{c}\text { Sigma-Aldrich (Prague, Czech } \\
\text { Republic) }\end{array}$ & 100 mg/kg (I.P.) & Pretreatment for $1 \mathrm{~h}$ & [88] \\
\hline Microcystins $38.11 \mu \mathrm{g} / \mathrm{kg} / 3$ h/I.P. & Male Swiss mice & & $300 \mathrm{mg} / \mathrm{kg}$ (oral) & 7 days pretreatment & [89] \\
\hline \multirow{2}{*}{ Biliary duct ligation (BDL) } & $\begin{array}{c}\text { Male Wistar albino rats (Rattus } \\
\text { novegiccus) }\end{array}$ & $\begin{array}{c}\text { curcumin (97\%, purity) from Sigma } \\
\text { Chemicals }\end{array}$ & $50 \mathrm{mg} / \mathrm{kg} /$ day in corn oil (oral) & 14 days & [90] \\
\hline & Male Wistar rats & $\begin{array}{l}\text { Curcumin (purity }>80 \% \text { ) from } \\
\text { Sigma Chemicals }\end{array}$ & $\begin{array}{l}100 \mathrm{mg} / \mathrm{kg} / \text { day in Carboxymethyl } \\
\text { cellulose (CMC) (oral) }\end{array}$ & 28 days & [91] \\
\hline Ischemia/reperfusion (I/R) & Female Wistar Albino rat & Sigma Chemical Co., USA & $100 \mathrm{mg} / \mathrm{kg}$ (I.P.) & 30 min pretreatment before $I / R$ & [92] \\
\hline $\begin{array}{l}\text { Acetaminophen (APAP) (750 } \\
\mathrm{mg} / \mathrm{kg} / \text { single dose /oral }\end{array}$ & Male Albino Wistar rats & Armal company & $200 \mathrm{mg} / \mathrm{kg}$ in corn oil (oral) & $\begin{array}{l}1 \mathrm{st}=24 \mathrm{~h} \text { before APA } \\
2 \mathrm{nd}=2 \mathrm{~h} \text { after APAP } \\
3 \mathrm{rd}=12 \mathrm{~h} \text { after APAP }\end{array}$ & [94] \\
\hline Gentamicin (100 mg/kg/I.P.) & Male albino rats & Sigma Chemical Co. & $\begin{array}{c}20 \mathrm{mg} / \mathrm{kg} / \text { every other day in } 1 \% \\
\text { CMC (oral) }\end{array}$ & 21 days & [95] \\
\hline \multicolumn{6}{|c|}{ Xenobiotics } \\
\hline Aflatoxin B1 $(25 \mu \mathrm{g} / \mathrm{kg})$ & Male Fischer rats & Sigma Chemical Company & $200 \mathrm{mg} / \mathrm{kg}$ & 90 days & [96] \\
\hline Lambda cyhalothrin & $\begin{array}{c}\text { Male albino rats (Rattus } \\
\text { norvegicus) }\end{array}$ & Sigma-Aldrich Chemical Co & $\begin{array}{c}200 \mathrm{mg} / \mathrm{kg} / \text { day suspended in PBS } \\
\text { (oral) }\end{array}$ & 4 weeks & [97] \\
\hline $\begin{array}{l}\mathrm{Hg}(0.6,1.2, \text { or } 2.4 \mathrm{mg} / \mathrm{kg} \text { in } \\
\text { saline } / \mathrm{IP} / \text { daily } / 3 \text { days })\end{array}$ & $\begin{array}{l}\text { Male and female Adult Wistar } \\
\text { rat }\end{array}$ & $\begin{array}{l}\text { Curcumin }(98 \%) \text { was provided by } \\
\text { Sigma, Saint Louis, Missouri, USA }\end{array}$ & $100 \mathrm{mg} / \mathrm{kg} / \mathrm{in}$ DMSO (SC) & $2 \mathrm{~h}$ pretreatment before $\mathrm{Hg}$ & [100] \\
\hline
\end{tabular}


Table 1. Cont.

\begin{tabular}{|c|c|c|c|c|c|}
\hline Liver Disease Type & $\begin{array}{c}\text { Experimental Model Used } \\
\text { (Animal, Strain, Genetic or } \\
\text { Dietary Liver Injury) }\end{array}$ & Curcumin Source & Dose and Formulation (Injection) & Duration of Treatment & Reference \\
\hline \multicolumn{6}{|c|}{$\mathrm{CCl}_{4}$} \\
\hline $\begin{array}{c}\text { (1:1 in olive oil) } 1 \mathrm{~mL} / \mathrm{kg} / \text { every } \\
\text { other day } / \mathrm{IP} / 4 \text { weeks }\end{array}$ & Male Sprague-Dawley rats & Curcuma longa L. (CLL, turmeric) & $200 \mathrm{mg} / \mathrm{kg} /$ day in PBS (oral) & 4 weeks & [98] \\
\hline $\begin{array}{c}\text { 1st model }=0.2 \mathrm{~mL} / \mathrm{kg} / 24 \mathrm{~h} \\
\text { 2nd model }=1 \mathrm{~mL} / \mathrm{kg}(1: 1 \mathrm{in} \mathrm{corn} \\
\text { oil }) / 2 \text { times per week, oral } / 4 \\
\text { weeks }\end{array}$ & Male Sprague-Dawley rats & Curcuma longa L. (Zingiberaceae) & $\begin{array}{c}50,100 \text { or } 200 \mathrm{mg} \mathrm{kg} / \text { day in corn } \\
\text { oil (oral) orally for } 4 \text { consecutive } \\
\text { days }\end{array}$ & $\begin{array}{c}\text { 1st }=4 \text { days before } \mathrm{CCl}_{4} \text { treatment } \\
\text { 2nd }=\text { during } \mathrm{CCl}_{4} \text { treatment for } 4 \\
\text { weeks }\end{array}$ & [99] \\
\hline $\begin{array}{l}30 \% \text { CCl4 in olive oil }(0.05 \mathrm{~mL} / 10 \\
\text { g/IP }\end{array}$ & $\begin{array}{l}\text { Fish Cyprinus carpio var. Jian } \\
\text { (Jian carp) }\end{array}$ & Sigma-Aldrich Chemical Co & $0.1 \%, 0.5 \%$, or $1.0 \%$ & 60 days before $\mathrm{CCl}_{4}$ treatment & [102] \\
\hline \multicolumn{6}{|c|}{ Hepatotoxicity } \\
\hline $\begin{array}{l}\text { Propanil } 20 \mathrm{mg} / \mathrm{kg} / 3 \text { times a } \\
\text { week/in olive oil (oral) }\end{array}$ & Albino rat & Sigma Chemical, USA & $\begin{array}{c}50 \mathrm{mg} / \mathrm{kg} / 3 \text { times a week/in olive } \\
\text { oil }\end{array}$ & 28 days & [95] \\
\hline $\begin{array}{c}\text { Paracetamol } 500 \mathrm{mg} / \mathrm{kg} / \text { day for } 15 \\
\text { days (oral) }\end{array}$ & Adult male rabbits & Sigma Chemical & 50 and $100 \mathrm{mg} / \mathrm{kg} /$ in corn oil (oral) & 15 days & [105] \\
\hline $\begin{array}{l}\text { Chloroquine phosphate (CQ) 100, } \\
200 \text { or } 300 / \text { daily } / 45 \mathrm{~d}\end{array}$ & Male Swiss Albino mice & - & $80 \mathrm{mg} / \mathrm{kg} /$ day (oral) & 45 days during $C Q$ treatment & {$[107]$} \\
\hline TAA $200 \mathrm{mg} / \mathrm{kg} / \mathrm{I} . P$. for 12 weeks & Male Wistar albino rats & - & $75 \mathrm{mg} / \mathrm{kg}$ (oral) & $\begin{array}{c}12 \text { weeks after discontinuation of } \\
\text { TAA }\end{array}$ & [108] \\
\hline $\begin{array}{c}\text { TAA } 300 \mathrm{mg} / \mathrm{kg} / 2 \\
\text { days/I.P./dissolved in a solution of } \\
\text { glycerol formal, chremaphore and } \\
\mathrm{H}_{2} \mathrm{O}(5: 2: 2)\end{array}$ & Male Wistar rats & Sigma Chemical & $\begin{array}{l}200 \text { or } 400 \mathrm{mg} / \mathrm{kg} / \text { day dissolved in } \\
\text { glycerol formal, chremaphore and } \\
\mathrm{H}_{2} \mathrm{O}(5: 2: 2) \text { (oral) }\end{array}$ & $\begin{array}{l}48 \mathrm{~h} \text { before TAA administration } \\
\text { then continued during the two } \\
\text { days of TAA injection }\end{array}$ & [109] \\
\hline LPS $1 \mathrm{mg} / \mathrm{kg} / \mathrm{I} . P$. & Male Wistar rats & $\begin{array}{l}\text { Sigma Aldrich Chemicals Private } \\
\text { Ltd., New Delhi, India }\end{array}$ & $\begin{array}{c}5,30 \text { or } 60 \mathrm{mg} / \mathrm{kg} / \text { suspended in } \\
0.5 \% \mathrm{CMC} \text { (oral) }\end{array}$ & $\begin{array}{c}6 \text { days before LPS injection and } \\
\text { sacrificed after } 6 \text { h post LPS } \\
\text { injection }\end{array}$ & [110] \\
\hline $\begin{array}{l}\text { Nzno } 50 \mathrm{mg} / \mathrm{kg} / \text { on } 7 \text { th day of } \\
\text { saline administration (oral) }\end{array}$ & Male Wistar rats & & $200 \mathrm{mg} / \mathrm{kg} /$ day $/$ in corn oil (oral) & $\begin{array}{l}7 \text { days prior } \mathrm{NZnO} \text { and continued } \\
\text { for } 21 \text { days }\end{array}$ & [111] \\
\hline $\begin{array}{c}\text { Naf } 600 \text { ppm via drinking water/7 } \\
\text { days }\end{array}$ & Male Wistar rats & Sigma-Aldrich Chemical, USA & $\begin{array}{c}10 \text { or } 20 \mathrm{mg} / \mathrm{kg} / \text { dissolved in } 5 \% \\
\text { DMSO (I.P.) }\end{array}$ & 7 days then exposed for 7 days $\mathrm{NaF}$ & [112] \\
\hline $\begin{array}{c}\text { (Tz, azo dye) } 7.5 \mathrm{mg} / \mathrm{kg} / \operatorname{diet} / 90 \\
\text { days }\end{array}$ & Male Wistar Albino rats & Local markets, Saudi Arabia & 1,2 or $4 \mathrm{~g} / \mathrm{kg}$ & 90 days & {$[113]$} \\
\hline $\begin{array}{c}\mathrm{K}_{2} \mathrm{Cr}_{2} \mathrm{O}_{7} 15 \mathrm{mg} / \mathrm{kg} / \mathrm{I} . P . / \text { single } \\
\text { dose }\end{array}$ & Male Wistar rats & $\begin{array}{c}\text { Sigma-Aldrich (St. Louis, MO, } \\
\text { USA). }\end{array}$ & $\begin{array}{c}400 \mathrm{mg} / \mathrm{kg} / \text { suspended in } 0.5 \% \\
\text { CMC (oral) }\end{array}$ & $\begin{array}{l}10 \text { days prior single dose of } \\
\mathrm{K}_{2} \mathrm{Cr}_{2} \mathrm{O}_{7} \text { for } 24 \mathrm{~h} \text { or } 48 \mathrm{~h}\end{array}$ & {$[114,115]$} \\
\hline
\end{tabular}


Table 1. Cont.

\begin{tabular}{|c|c|c|c|c|c|}
\hline Liver Disease Type & $\begin{array}{l}\text { Experimental Model Used } \\
\text { (Animal, Strain, Genetic or } \\
\text { Dietary Liver Injury) }\end{array}$ & Curcumin Source & Dose and Formulation (Injection) & Duration of Treatment & Reference \\
\hline \multicolumn{6}{|c|}{ Fibrosis and Cirrhosis } \\
\hline $\begin{array}{l}\text { TAA } 200 \mathrm{mg} / \mathrm{kg} / \mathrm{I} . \mathrm{P} . / \mathrm{tw} \text { wice a week } \\
\text { for } 12 \text { weeks }\end{array}$ & Male Wistar rats & - & $\begin{array}{c}300 \mathrm{mg} / \mathrm{kg} / \text { day } / \text { in solvent } / 2 \mathrm{~mL} \\
\text { per rat } \\
\text { (intragingival) }\end{array}$ & $\begin{array}{l}12 \text { weeks along with TAA or } 4 \text { or } 6 \\
\text { weeks after TAA discontinuation }\end{array}$ & [116] \\
\hline \multirow{3}{*}{ Biliary duct ligation } & Male Wistar Albino rats & Sigma-Aldrich, USA & $100 \mathrm{mg} / \mathrm{kg} /$ day (oral) & $\begin{array}{l}\text { 1st dose }=3 \text { days before BDL and } \\
\text { terminated after } 14 \text { days }\end{array}$ & [120] \\
\hline & Male Wistar Albino rats & $\begin{array}{c}\text { Sigma Chemicals Co Purity (HPLC) } \\
>80 \% \text {, USA }\end{array}$ & $\begin{array}{c}100 \mathrm{mg} / \mathrm{kg} / \text { day } / \text { suspended in } 5 \% \\
\text { CMC (oral) }\end{array}$ & 28 days after BDL surgery & [118] \\
\hline & Male Wistar rats & Sigma Chemicals Co, USA & $\begin{array}{c}100 \mathrm{mg} / \mathrm{kg} / \text { day } / \text { suspended in } \\
0.7 \% \text { CMC (oral) }\end{array}$ & 28 days & [117] \\
\hline $\begin{array}{c}\mathrm{CCl}_{4} 0.4 \mathrm{~g} / \mathrm{kg} / 3 \text { times per } \\
\text { week/dissolved in mineral oil/for } \\
3 \text { months }\end{array}$ & Male Wistar rats & Sigma Chemicals Co, USA & $100 \mathrm{mg} / \mathrm{kg} /$ day (oral) & 2 months & [117] \\
\hline LPS $5 \mathrm{mg} / \mathrm{kg} / \mathrm{I} . P$. & Male C57BL/ 6 mice & - & 20,40 or $80 \mathrm{mg} / \mathrm{kg} /$ day (oral & 4 weeks & [121] \\
\hline
\end{tabular}




\subsection{Role of Epigenetic Pathway in Protective Effect of Curcumin against Oxidative Associated Liver Diseases}

Epigenetics, reversible alterations in gene expression, regulates the chromatin structure modifications and the initiation of transcription by altering the gene transcription without changing the primary DNA sequence [122]. There is a link between oxidative stress, epigenetics and NAFLD through the mitochondria. Epigenetic mechanisms have a crucial role in the pathophysiology of NAFLD and epigenetic causes of oxidative stress contribute to NAFLD [123]. The most studied epigenetic mechanisms are: (a) DNA methylation; (b) histone modifications; and (c) microRNAs (miRs) [122].

DNA methylation, the first discovery of epigenetic regulation of gene expression, is a biochemical modification (methylation) of cytosine-phosphoguanine $(\mathrm{CpG})$ dinucleotides in promoter regions that is regulated by DNA methyltransferases (DNMTs) [124,125]. Increasing the level of Methyl-CpG binding protein 2 (MECP2) activates HSCs and promotes fibrosis by repressing peroxisome proliferator-activated receptor $\gamma(\operatorname{PPAR} \gamma)$ [124]. Also, epigenetic variations in mitochondrial DNA methylation can cause abnormal gene expression in NAFLD [125]. Among post-translational modifications of histones, acetylation that is usually associated with the activation of gene transcription affects the gene expression in NAFLD [122,125]. MiRs, small noncoding RNAs, regulate post-transcriptional gene expression through degradation or repression of mRNAs. Activation and inactivation of HSCs can be controlled by miRs [124]. In addition, several targets for treatment of NAFLD have been proposed by this mechanism [125]. Hence, among epigenetic machineries, miRs are the most widely investigated in NAFLD [122].

It has been demonstrated that curcumin can reduce the occurrence and/or delay the development of HCC by epigenetic mechanisms such as DNA demethylation and histone deacetylases (HDAC)-inhibitory effect [126]. Furthermore, Curcumin can modulate miRs in liver diseases [127]. A novel mechanism suppressing liver fibrosis by Zheng et al., resulted in the inhibition of cell proliferation and up-regulation of the Phosphatase and tensin homologue deleted on chromosome 10 (PTEN) expression through microRNA-mediated control of DNA methylation after curcumin treatment [128]. Liu et al. showed that the administration of curcumin modulated the growth of human breast cancer cell line MDA-MB-361 and induced the Deleted in Liver Cancer 1 (DLC1) expression. In this study CpG demethylation of many tumor suppressor genes was conducted and inhibition of DNA methyltransferase 1 expression by decreasing the expression of transcription factor Sp1 was observed [129]. In another study, Yuan et.al. investigated the effect of the DNA methylation inhibitor 5-Aza-CdR and curcumin on DNA methylation of the PPAR- $\alpha$ gene in NAFLD pathogenesis. They found that gene expression was regulated through epigenetic modifications, DNA methylation levels were reversed and lipid accumulation was improved [130].

\section{Nanoformulations of Curcumin in Oxidative Associated Liver Diseases}

The first report on the bioavailability of curcumin was in 1978 [131]. The study showed that traces of curcumin could be identified in the plasma of rats receiving $50 \mathrm{mg} / \mathrm{kg}$ intravenously. This fact indicated the poor absorption of curcumin. Another study showed that low levels of curcumin could be detected in the plasma after oral administration of high dose, representing the low absorption from the intestine [132]. More experiments have been performed in order to understand the reason behind the poor bioavailability and distribution of curcumin in liver, spleen and kidney or heart [131-134].

These circumstances opened another area of research with the aim of improving the bioavailability either by encapsulation of curcumin in phosphatidyl-choline (Meriva ${ }^{\circledR}$ ) [134] or by nanoformulation to increase drug delivery. Phosphatidyl-choline coating increased the detectable level of curcumin and its metabolites in the plasma and the liver [134]. Zein, a corn protein, recently was used to improve the bioavailability of curcumin and liver targeting [135]. Zein has been used in many pharmaceutical products due to its low side effects, slow release of the drug and targeting the liver [136, 137]. Algandaby et al. formulated curcumin-zein nanospheres and investigated the efficiency of the product in treating liver fibrosis in $\mathrm{CCl}_{4}$-treated mouse model. The study confirmed the increase in liver 
targeting (3.24 fold) by determination of curcumin level in liver and plasma. Curcumin-zein (cur-zein) form decreased aminotransferases and ALP levels. Additionally, absence of fibrosis and ballooning degeneration and fat accumulation reduction in liver sections were also observed. Therefore, cur-zein improved the curcumin antifibrotic activity in comparison to curcumin alone.

A report by Ahmad et al. 2018 [138] described the formation of nanocomposite of curcumin with chitosan. This material increased the hepatoprotective activity of curcumin. Pretreatment of mice with curcumin-chitosan nanospheres elevated the antioxidant enzymes (SOD, GSH, GST and catalase) and protected the mouse from cadmium toxicity. For improving the bioavailability of curcumin, Singh et al. evaluated the efficacy of curcumin-solid lipid nanoparticles (C-SLNs) on $\mathrm{CCl}_{4}$-induced hepatic injury in rats compared to curcumin alone. Microemulsification method was used to prepare C-SLNs with size of $147.6 \mathrm{~mm}$. Using of C-SLNs $(12.5 \mathrm{mg} / \mathrm{kg})$ was more effective and reduced oxidative stress, histopathological alterations as well as TNF- $\alpha$, serum ALT and AST [139].

\section{Clinical Studies Supporting the Efficacy of Curcumin in Oxidative Associated Liver Diseases}

The animal studies confirmed the ability of curcumin in lowering lipogenesis, oxidative stress and increasing insulin sensitivity $[140,141]$. On the other hand, human clinical studies on the bioavailability and efficacy of curcumin have been mainly performed on patients with cancer or diabetes. The results showed that curcumin is characterized by low systemic bioavailability with rapid metabolism in liver and excretion [142].

Two recent articles that investigated the role of curcumin in prevention and treatment of NAFLD, are listed in Table $2[143,144]$. Panahi et al. performed a randomized controlled study with 87 individuals, 44 patients ( 20 females and 24 males) were diagnosed with NAFLD and categorized into grades from 1 to 3 according to the liver ultrasonography. Patients group received two doses of curcumin (1000 mg/day) in phytosomal capsules. After 8 weeks, liver aminotransferases and ultrasonography with anthropometric parameters were evaluated in patients and the placebo group. Panahi et al. showed the ability of curcumin phytosomal to reduce the body mass index $(-0.99 \pm 1.25)$ versus the placebo group $(-0.15 \pm 1.31)$. Curcumin-receiving group showed a remarkable decrease in liver enzymes AST, ALT, serum glutamic oxaloacetic transaminase (SGOT) and serum glutamate-pyruvate transaminase (SGPT) levels. Moreover, liver sonography was improved within patients treated with curcumin where the portal vein diameter decreased and vein flow was increased. Curcumin also decreased the NAFLD severity by decreasing the fat content in the liver. The aforementioned results by Panahi et al. confirmed the efficacy of curcumin supplementation for short period in treating NAFLD [144].

Table 2. Clinical studies of curcumin used in the treatment of oxidative associated liver diseases.

\begin{tabular}{|c|c|c|c|c|c|}
\hline Dose & Study Design & No. of Patients & $\begin{array}{l}\text { Duration of } \\
\text { Treatment }\end{array}$ & Result & Reference \\
\hline $\begin{array}{c}1000 \\
\mathrm{mg} / \text { day }\end{array}$ & $\begin{array}{l}\text { Patients with NAFLD were } \\
\text { randomly assigned to the } \\
\text { curcumin }(n=44) \text { or placebo } \\
\text { group }(n=43)\end{array}$ & 87 & 8 weeks & $\begin{array}{l}\downarrow \text { the body } \\
\text { mass index, } \\
\text { AST, ALT, } \\
\text { SGOT, SGPT }\end{array}$ & [144] \\
\hline
\end{tabular}

Another randomized double-blinded placebo study was carried out to investigate the ability of curcumin in treating NAFLD [143]. This study used a lower dose of curcumin (500 mg/day) in amorphous form and for the same short period ( 8 weeks). Total 80 subjects participated in the clinical study. Only 40 patients received curcumin daily. Rahmani et al. evaluated the anthropometric measurements, liver aminotransferases, low-density lipoprotein-cholesterol (LDL-C), triglyceride, 
glucose, cholesterol, high-density lipoprotein-cholesterol (HDL-C) and glycated hemoglobin (HbA1c). After 8 weeks of supplementation with curcumin, the waist circumference, Body mass index (BMI) and weight were significantly reduced. In addition, total cholesterol and LDL-C were decreased while HDL-C was elevated. The other biochemical parameters such as aminotransferases (ALT and AST) were reduced by the end of the trial. In order to confirm the ability and efficacy of curcumin in treating NAFLD, a histological sample of liver should be collected but this is an invasive procedure and holds a risk of morbidity. Liver sonography with biochemical parameters is an excellent alternative technique to show the improvement [145]. In this clinical trial, liver sonography showed that curcumin improved the NAFLD sonography grade to $78.9 \%$, where grade 3 was not detected in the participants, grade 2 was detected in only $13.2 \%$ of patients and $15.8 \%$ were completely improved.

As discussed previously, curcumin has low bioavailability. However, several clinical trials as well as preclinical studies confirmed the protective and therapeutic effects of curcumin in different oxidative associated diseases including liver disorders. Different evidences have suggested that the therapeutic activities of this natural molecule, despite its undesirable pharmacokinetic properties, is mainly due to the main metabolites of curcumin, which may have a key role in the biological function $[146,147]$.

\section{Conclusions}

Curcumin is able to protect and treat liver diseases and to alter different cellular pathways. For instance, curcumin induce the expression of heme oxygenase-1 [148] which cleaves heme and produces CO, biliverdien and bilirubin and other antioxidant molecules [149]. Regarding the reported effects on cellular responses, curcumin inhibits activation and proliferation of HSC, leading to a decrease in production of extracellular matrix collagen and protecting liver from fibrogenesis [83]. This effect on HSC was found to be through the down-regulation of PDGF- $\beta$ R, EGFR and TGF- $\beta$ coupled with the reduction of mRNA level of PPAR- $\gamma[150,151]$. Curcumin induced the synthesis of reduced glutathione [152] leading to a marked decrease in lipid peroxidation products such as lipid hydroperoxide and MDA $[83,84]$. The increase in GSH level is due to the ability of curcumin in elevating the gene expression of the rate-limiting enzyme in glutathione synthesis and glutamate cysteine ligase (GCL) [83]. Curcumin treatment leads to a marked decrease in the level of proinflammatory cytokines such as TNF- $\alpha$, INF- $\gamma$, IL-1 $\beta$ and IL-6 $[84,153]$. The decrease in proinflammatory cytokines was due to the inhibition of NF- $\mathrm{KB}$ translocation to the nucleus and decreasing its DNA binding activity [84].

Curcumin increased the expression of SIRT3, a NAD -dependent deacetylase and ADP-ribosyltransferase. SIRT3 activation by curcumin led to the decrease in lipid deposition through AMPK and the mitochondrial CPT-1A. Moreover, SIRT3 caused a decrease in ROS level by upregulating the expression of MnSOD and the mitochondrial IDH2 [118]. Another signaling cellular pathway attenuated in the liver by curcumin treatment is PI3K/Akt. Hence, curcumin inhibited and decreased the level of apoptotic markers such as Bad, Bcl-xL, cytochrome $c$, Apaf-1, cleaved caspase-9, -3 and - 6 . p38 mitogen-activated protein kinase/JUN was also downregulated and protected the liver cells from death [121]. Also, curcumin downregulated the expression of ACE [108].

A wide variety of preclinical studies support the effectiveness of dietary curcumin in the management of oxidative associated liver diseases. However, there are few RCTs assessing the efficacy of curcumin in liver disorders. Table 2 exhibits the evidence of curcumin in the prevention and treatment of oxidative associated liver diseases in humans. Further well-designed RCTs are therefore required to confirm the dietary and adjunctive role of curcumin as promising protective or curative agent in the management of oxidative associated liver diseases.

To conclude, the results obtained from the present review revealed that curcumin can be effective in various types of oxidative associated liver disorders. This potentiality attributes to curcumin effects on hepatotoxicity, non-alcoholic steatohepatitis, alcoholic liver disease, liver fibrosis and cirrhosis as well as hepatic injury. Experimental evidences indicate that curcumin exhibits its preventive and curative effect against oxidative associated liver diseases through various cellular signaling pathways. Those pathways include ERK/p38/MAPK pathway, hepatic Nrf2/ARE/Keap1 signaling, 
up-regulation of detoxifying genes expression, TIMP signaling, AMPK pathway and lipid metabolism, as well as down-regulation of Rac1, NOX1 and Rac1-GTP transduction. Regarding the above mentioned biological activities of curcumin in either protecting or treating liver, it is highly recommended to consider curcumin as a safe and effective natural product for oxidative associated liver diseases. Among the studies that were conducted in various oxidative models associated liver disease, some investigated the protective effects of curcumin [83-86,97,98,105-107]. According to these articles, curcumin as a dietary supplement has a protective role against the onset of liver diseases. The intake of a significant content of curcumin in the daily regimen or as dietary supplementation along with restricted therapeutic options can provide perfect prevention and treatment for liver disorders. Present review revealed that further in vitro and preclinical studies are encouraged to recognize the exact bioavailability, bioefficacy and cellular transduction signaling pathways of curcumin in managing oxidative associated liver diseases.

Author Contributions: M.H.F. and M.Z. designed the structure of the paper and drafted the manuscript. F.P., F.F.E.-S., I.M., E.C.-B. and R.N. performed the literature search and contributed in writing the manuscript. S.M.N., R.R. and M.A. reviewed and revised the manuscript. All authors have seen and approved the final version of the manuscript.

Funding: This research received no external funding.

Acknowledgments: This article is the outcome of an in-house financially non-supported study.

Conflicts of Interest: The authors declare no conflicts of interest.

\section{References}

1. Muriel, P. The Liver: General Aspects and Epidemiology. In Liver Pathophysiology; Elsevier: Amsterdam, The Netherlands, 2017; pp. 3-22.

2. Cichoż-Lach, H.; Michalak, A. Oxidative Stress as a Crucial Factor in Liver Diseases. World J. Gastroenterol. 2014, 20, 8082. [CrossRef] [PubMed]

3. Clark, A.M. Natural products as a resource for new drugs. Pharm. Res. 1996, 13, 1133-1141. [CrossRef] [PubMed]

4. Harvey, A. Strategies for discovering drugs from previously unexplored natural products. Drug Discov. Today 2000, 5, 294-300. [CrossRef]

5. Gordaliza, M. Natural products as leads to anticancer drugs. Clin. Transl. Oncol. 2007, 9, 767-776. [CrossRef] [PubMed]

6. Zhang, A.; Sun, H.; Wang, X. Recent advances in natural products from plants for treatment of liver diseases. Eur. J. Med. Chem. 2013, 63, 570-577. [CrossRef] [PubMed]

7. Xiao, J.; So, K.F.; Liong, E.C.; Tipoe, G.L. Recent advances in the herbal treatment of non-alcoholic Fatty liver disease. J. Tradit. Complement. Med. 2013, 3, 88-94. [CrossRef] [PubMed]

8. Sun Kim, M.; Kung, S.; Grewal, T.; D Roufogalis, B. Methodologies for investigating natural medicines for the treatment of nonalcoholic fatty liver disease (NAFLD). Curr. Pharm. Biotechnol. 2012, 13, 278-291. [CrossRef]

9. Maheshwari, R.K.; Singh, A.K.; Gaddipati, J.; Srimal, R.C. Multiple biological activities of curcumin: A short review. Life Sci. 2006, 78, 2081-2087. [CrossRef] [PubMed]

10. Bahramsoltani, R.; Rahimi, R.; Farzaei, M.H. Pharmacokinetic interactions of curcuminoids with conventional drugs: A review. J. Ethnopharmacol. 2017, 209, 1-2. [CrossRef] [PubMed]

11. Srimal, R.; Dhawan, B. Pharmacology of diferuloyl methane (curcumin), a non-steroidal anti-inflammatory agent. J. Pharm. Pharmacol. 1973, 25, 447-452. [CrossRef] [PubMed]

12. Satoskar, R.; Shah, S.; Shenoy, S. Evaluation of anti-inflammatory property of curcumin (diferuloyl methane) in patients with postoperative inflammation. Int. J. Clin. Pharmacol. Ther. Toxicol. 1986, 24, 651-654. [PubMed]

13. Kuttan, R.; Bhanumathy, P.; Nirmala, K.; George, M. Potential anticancer activity of turmeric (Curcuma longa). Cancer Lett. 1985, 29, 197-202. [CrossRef]

14. Sharma, O. Antioxidant activity of curcumin and related compounds. Biochem. Pharmacol. 1976, 25, 1811-1812. [CrossRef] 
15. Sidhu, G.S.; Singh, A.K.; Thaloor, D.; Banaudha, K.K.; Patnaik, G.K.; Srimal, R.C.; Maheshwari, R.K. Enhancement of wound healing by curcumin in animals. Wound Repair Regen. 1998, 6, 167-177. [CrossRef] [PubMed]

16. Blachier, M.; Leleu, H.; Peck-Radosavljevic, M.; Valla, D.-C.; Roudot-Thoraval, F. The Burden of Liver Disease in Europe: A Review of Available Epidemiological Data. J. Hepatol. 2013, 58, 593-608. [CrossRef] [PubMed]

17. Tsutsumi, V.; Nakamura, T.; Ueno, T.; Torimura, T.; Aguirre-García, J. Structure and Ultrastructure of the Normal and Diseased Liver. In Liver Pathophysiology; Elsevier: Amsterdam, The Netherlands, 2017; pp. $23-44$.

18. Ueno, T.; Sugawara, H.; Sujaku, K.; Hashimoto, O.; Tsuji, R.; Tamaki, S.; Torimura, T.; Inuzuka, S.; Sata, M.; Tanikawa, K. Therapeutic Effects of Restricted Diet and Exercise in Obese Patients with Fatty Liver. J. Hepatol. 1997, 27, 103-107. [CrossRef]

19. Aita, K.; Jin, Y.; Irie, H.; Takahashi, I.; Kobori, K.; Nakasato, Y.; Kodama, H.; Yanagawa, Y.; Yoshikawa, T.; Shiga, J. Are There Histopathologic Characteristics Particular to Fulminant Hepatic Failure Caused by Human Herpesvirus-6 Infection? A Case Report and Discussion. Hum. Pathol. 2001, 32, 887-889. [CrossRef] [PubMed]

20. Sasaki, N.; Ueno, T.; Morita, Y.; Nagata, E.; Sata, M. Usefulness of Serum Hepatic Fibrosis Markers in the Diagnosis of Nonalcoholic Steatohepatitis (NASH). Hepatogastroenterology 2006, 53, 678-681. [PubMed]

21. Morita, Y.; Ueno, T.; Sasaki, N.; Kuhara, K.; Yoshioka, S.; Tateishi, Y.; Nagata, E.; Kage, M.; Sata, M. Comparison of Liver Histology Between Patients with Non-Alcoholic Steatohepatitis and Patients with Alcoholic Steatohepatitis in Japan. Alcohol. Clin. Exp. Res. 2005, 29. [CrossRef]

22. Wanless, I.R.; Lentz, J.S. Fatty liver hepatitis (steatohepatitis) and obesity: An autopsy study with analysis of risk factors. Hepatology 1990, 12, 1106-1110. [CrossRef] [PubMed]

23. Bellentani, S.; Saccoccio, G.; Masutti, F.; Crocè, L.S.; Brandi, G.; Sasso, F.; Cristanini, G.; Tiribelli, C. Prevalence of and risk factors for hepatic steatosis in Northern Italy. Ann. Intern. Med. 2000, 132, 112-117. [CrossRef] [PubMed]

24. Lonardo, A.; Loria, P.; Leonardi, F.; Borsatti, A.; Neri, P.; Pulvirenti, M.; Verrone, A.M.; Bagni, A.; Bertolotti, M.; Ganazzi, D.; et al. Fasting insulin and uric acid levels but not indices of iron metabolism are independent predictors of non-alcoholic fatty liver disease. A case-control study. Dig. Liver Dis. 2002, 34, $204-211$. [CrossRef]

25. Omagari, K.; Kadokawa, Y.; Masuda, J.; Egawa, I.; Sawa, T.; Hazama, H.; Ohba, K.; Isomoto, H.; Mizuta, Y.; Hayashida, K.; et al. Fatty liver in non-alcoholic non-overweight Japanese adults: Incidence and clinical characteristics. J. Gastroenterol. Hepatol. 2002, 17, 1098-1105. [CrossRef] [PubMed]

26. Promrat, K.; Lutchman, G.; Uwaifo, G.I.; Freedman, R.J.; Soza, A.; Heller, T.; Doo, E.; Ghany, M.; Premkumar, A.; Park, Y. A pilot study of pioglitazone treatment for nonalcoholic steatohepatitis. Hepatology 2004, 39, 188-196. [CrossRef] [PubMed]

27. Sanyal, A.J.; Mofrad, P.S.; Contos, M.J.; Sargeant, C.; Luketic, V.A.; Sterling, R.K.; Stravitz, R.T.; Shiffman, M.L.; Clore, J.; Mills, A.S. A pilot study of vitamin E versus vitamin E and pioglitazone for the treatment of nonalcoholic steatohepatitis. Clin. Gastroenterol. Hepatol. 2004, 2, 1107-1115. [CrossRef]

28. Nesto, R.W.; Bell, D.; Bonow, R.O.; Fonseca, V.; Grundy, S.M.; Horton, E.S.; le Winter, M.; Porte, D.; Semenkovich, C.F.; Smith, S. Thiazolidinedione use, fluid retention, and congestive heart failure: A consensus statement from the American Heart Association and American Diabetes Association. Circulation 2003, 108, 2941-2948. [CrossRef] [PubMed]

29. Sanyal, A.J. Treatment of non-alcoholic fatty liver disease. J. Gastroenterol. Hepatol. 2002, 17, S385-S388. [CrossRef] [PubMed]

30. Hussain, S.P.; Schwank, J.; Staib, F.; Wang, X.W.; Harris, C.C. TP53 Mutations and Hepatocellular Carcinoma: Insights into the Etiology and Pathogenesis of Liver Cancer. Oncogene 2007, 26, 2166. [CrossRef] [PubMed]

31. Turrens, J.F. Mitochondrial Formation of Reactive Oxygen Species. J. Physiol. 2003, 552, 335-344. [CrossRef] [PubMed]

32. Zorov, D.B.; Juhaszova, M.; Sollott, S.J. Mitochondrial Reactive Oxygen Species (ROS) and ROS-Induced ROS Release. Physiol. Rev. 2014, 94, 909-950. [CrossRef] [PubMed]

33. Bailey, S.M.; Cunningham, C.C. Contribution of Mitochondria to Oxidative Stress Associated with Alcoholic Liver disease1. Free Radic. Biol. Med. 2002, 32, 11-16. [CrossRef] 
34. Palma, H.E.; Wolkmer, P.; Gallio, M.; Corrêa, M.M.B.; Schmatz, R.; Thomé, G.R.; Pereira, L.B.; Castro, V.S.P.; Pereira, A.B.; Bueno, A. Oxidative Stress Parameters in Blood, Liver, and Kidney of Diabetic Rats Treated with Curcumin And/or Insulin. Mol. Cell. Biochem. 2014, 386, 199-210. [CrossRef] [PubMed]

35. Bailey, S.M.; Cunningham, C.C. Acute and Chronic Ethanol Increases Reactive Oxygen Species Generation and Decreases Viability in Fresh, Isolated Rat Hepatocytes. Hepatology 1998, 28, 1318-1326. [CrossRef] [PubMed]

36. Wang, H.; Chen, X.; Su, Y.; Paueksakon, P.; Hu, W.; Zhang, M.-Z.; Harris, R.C.; Blackwell, T.S.; Zent, R.; Pozzi, A. p47phox Contributes to Albuminuria and Kidney Fibrosis in Mice. Kidney Int. 2015, 87, 948-962. [CrossRef] [PubMed]

37. Li, S.; Tan, H.-Y.; Wang, N.; Zhang, Z.-J.; Lao, L.; Wong, C.-W.; Feng, Y. The Role of Oxidative Stress and Antioxidants in Liver Diseases. Int. J. Mol. Sci. 2015, 16, 26087-26124. [CrossRef] [PubMed]

38. Videla, L.A. Oxidative Stress Signaling Underlying Liver Disease and Hepatoprotective Mechanisms. World J. Hepatol. 2009, 1, 72. [CrossRef] [PubMed]

39. Karabulut, A.B.; Gül, M.; Karabulut, E.; Kiran, T.R.; Ocak, S.G.; Otlu, O. Oxidant and Antioxidant Activity in Rabbit Livers Treated with Zoledronic Acid. Transpl. Proc. 2010, 42, 3820-3822.

40. Ozgur, E.; Güler, G.; Seyhan, N. Mobile Phone Radiation-Induced Free Radical Damage in the Liver Is Inhibited by the Antioxidants N-Acetyl Cysteine and Epigallocatechin-Gallate. Int. J. Radiat. Biol. 2010, 86, 935-945. [CrossRef] [PubMed]

41. Bando, I.; Reus, M.I.S.; Andrés, D.; Cascales, M. Endogenous Antioxidant Defence System in Rat Liver Following Mercury Chloride Oral Intoxication. J. Biochem. Mol. Toxicol. 2005, 19, 154-161. [CrossRef] [PubMed]

42. Negi, A.S.; Kumar, J.K.; Luqman, S.; Shanker, K.; Gupta, M.M.; Khanuja, S.P.S. Recent Advances in Plant Hepatoprotectives: A Chemical and Biological Profile of Some Important Leads. Med. Res. Rev. 2008, 28, 746-772. [CrossRef] [PubMed]

43. Araujo, C.A.C.; Leon, L.L. Biological Activities of Curcuma Longa L. Mem. Inst. Oswaldo Cruz 2001, 96, 723-728. [CrossRef] [PubMed]

44. Zhongfa, L.; Chiu, M.; Wang, J.; Chen, W.; Yen, W.; Fan-Havard, P.; Yee, L.D.; Chan, K.K. Enhancement of curcumin oral absorption and pharmacokinetics of curcuminoids and curcumin metabolites in mice. Cancer Chemother. Pharmacol. 2012, 69, 679-689. [CrossRef] [PubMed]

45. Ak, T.; Gülçin, İ. Antioxidant and Radical Scavenging Properties of Curcumin. Chem. Biol. Interact. 2008, 174, 27-37. [CrossRef] [PubMed]

46. Martín-Aragón, S.; Benedí, J.M.; Villar, A.M. Modifications on Antioxidant Capacity and Lipid Peroxidation in Mice under Fraxetin Treatment. J. Pharm. Pharmacol. 1997, 49, 49-52. [CrossRef] [PubMed]

47. Rao, M.N.A. Nitric Oxide Scavenging by Curcuminoids. J. Pharm. Pharmacol. 1997, 49, 105-107.

48. Menon, V.P.; Sudheer, A.R. Antioxidant and Anti-Inflammatory Properties of Curcumin. In The molecular Targets and Therapeutic Uses of Curcumin in Health and Disease; Springer: Berlin, Germany, 2007; pp. 105-125.

49. Balogun, E.; Hoque, M.; Gong, P.; Killeen, E.; Green, C.J.; Foresti, R.; Alam, J.; Motterlini, R. Curcumin Activates the Haem Oxygenase-1 Gene via Regulation of Nrf2 and the Antioxidant-Responsive Element. Biochem. J. 2003, 371 Pt 3, 887. [CrossRef] [PubMed]

50. Jha, N.S.; Mishra, S.; Jha, S.K.; Surolia, A. Antioxidant Activity and Electrochemical Elucidation of the Enigmatic Redox Behavior of Curcumin and Its Structurally Modified Analogues. Electrochim. Acta 2015, 151, 574-583. [CrossRef]

51. Kant, V.; Gopal, A.; Pathak, N.N.; Kumar, P.; Tandan, S.K.; Kumar, D. Antioxidant and Anti-Inflammatory Potential of Curcumin Accelerated the Cutaneous Wound Healing in Streptozotocin-Induced Diabetic Rats. Int. Immunopharmacol. 2014, 20, 322-330. [CrossRef] [PubMed]

52. Wright, J.S. Predicting the Antioxidant Activity of Curcumin and Curcuminoids. J. Mol. Struct. THEOCHEM 2002, 591, 207-217. [CrossRef]

53. Barclay, L.R.C.; Vinqvist, M.R.; Mukai, K.; Goto, H.; Hashimoto, Y.; Tokunaga, A.; Uno, H. On the Antioxidant Mechanism of Curcumin: Classical Methods Are Needed to Determine Antioxidant Mechanism and Activity. Org. Lett. 2000, 2, 2841-2843. [CrossRef] [PubMed]

54. Andrea, M.; Cinzia, C.; Sergio, L.; van Beek Teris, A.; Luca, G.; Francesco, R.S.; Jules, B. Production of Novel Antioxidative Phenolic Amides through Heterologous Expression of the Plant's Chlorogenic Acid Biosynthesis Genes in Yeast. Metab. Eng. 2010, 12, 223-232. [CrossRef] [PubMed] 
55. Priyadarsini, K.I.; Maity, D.K.; Naik, G.H.; Kumar, M.S.; Unnikrishnan, M.K.; Satav, J.G.; Mohan, H. Role of Phenolic $\mathrm{OH}$ and Methylene Hydrogen on the Free Radical Reactions and Antioxidant Activity of Curcumin. Free Radic. Biol. Med. 2003, 35, 475-484. [CrossRef]

56. Shen, L.; Zhang, H.-Y.; Ji, H.-F. Successful Application of TD-DFT in Transient Absorption Spectra Assignment. Org. Lett. 2005, 7, 243-246. [CrossRef] [PubMed]

57. Sharma, R.A.; Gescher, A.J.; Steward, W.P. Curcumin: The Story so Far. Eur. J. Cancer 2005, 41, $1955-1968$. [CrossRef] [PubMed]

58. Hismiogullari, S.E.; Hismiogullari, A.A.; Sunay, F.B.; Paksoy, S.; Can, M.; Aksit, H.; Karaca, O.; Yavuz, O. The protective effect of curcumin on carbon tetrachloride induced liver damage. Revue Méd. Vét. 2014, 165, 194-200.

59. Vizzutti, F.; Provenzano, A.; Galastri, S.; Milani, S.; Delogu, W.; Novo, E.; Caligiuri, A.; Zamara, E.; Arena, U.; Laffi, G.; et al. Curcumin limits the fibrogenic evolution of experimental steatohepatitis. Lab. Investig. 2010, 90, 104-115. [CrossRef] [PubMed]

60. Li, B.; Wang, L.; Lu, Q.; Da, W. Liver injury attenuation by curcumin in a rat NASH model: An Nrf2 activation-mediated effect? Ir. J. Med. Sci. 2016, 185, 93-100. [CrossRef] [PubMed]

61. Afrin, R.; Arumugam, S.; Rahman, A.; Wahed, M.I.; Karuppagounder, V.; Harima, M.; Suzuki, H.; Miyashita, S.; Suzuki, K.; Yoneyama, H.; et al. Curcumin ameliorates liver damage and progression of NASH in NASH-HCC mouse model possibly by modulating HMGB1-NF-kappaB translocation. Int. Immunopharmacol. 2017, 44, 174-182. [CrossRef] [PubMed]

62. Saberi, B.; Dadabhai, A.S.; Jang, Y.Y.; Gurakar, A.; Mezey, E. Current Management of Alcoholic Hepatitis and Future Therapies. J. Clin. Transl. Hepatol. 2016, 4, 113-122. [PubMed]

63. Samuhasaneeto, S.; Thong-Ngam, D.; Kulaputana, O.; Suyasunanont, D.; Klaikeaw, N. Curcumin decreased oxidative stress, inhibited NF-kappaB activation, and improved liver pathology in ethanol-induced liver injury in rats. J. Biomed. Biotechnol. 2009, 2009, 981963. [CrossRef] [PubMed]

64. Lee, H.I.; McGregor, R.A.; Choi, M.S.; Seo, K.I.; Jung, U.J.; Yeo, J.; Kim, M.J.; Lee, M.K. Low doses of curcumin protect alcohol-induced liver damage by modulation of the alcohol metabolic pathway, CYP2E1 and AMPK. Life Sci. 2013, 93, 693-699. [CrossRef] [PubMed]

65. Bao, W.; Li, K.; Rong, S.; Yao, P.; Hao, L.; Ying, C.; Zhang, X.; Nussler, A.; Liu, L. Curcumin alleviates ethanol-induced hepatocytes oxidative damage involving heme oxygenase-1 induction. J. Ethnopharmacol. 2010, 128, 549-553. [CrossRef] [PubMed]

66. Rong, S.; Zhao, Y.; Bao, W.; Xiao, X.; Wang, D.; Nussler, A.K.; Yan, H.; Yao, P.; Liu, L. Curcumin prevents chronic alcohol-induced liver disease involving decreasing ROS generation and enhancing antioxidative capacity. Phytomedicine 2012, 19, 545-550. [CrossRef] [PubMed]

67. Xiong, Z.E.; Dong, W.G.; Wang, B.Y.; Tong, Q.Y.; Li, Z.Y. Curcumin attenuates chronic ethanol-induced liver injury by inhibition of oxidative stress via mitogen-activated protein kinase/nuclear factor E2-related factor 2 pathway in mice. Pharmacogn. Mag. 2015, 11, 707-715. [PubMed]

68. Varatharajalu, R.; Garige, M.; Leckey, L.C.; Reyes-Gordillo, K.; Shah, R.; Lakshman, M.R. Protective role of dietary curcumin in the prevention of the oxidative stress induced by chronic alcohol with respect to hepatic injury and antiatherogenic markers. Oxid. Med. Cell Longev. 2016, 2016, 5017460. [CrossRef] [PubMed]

69. Zhao, H.L.; Song, C.H.; Chai, O.H. Negative effects of curcumin on liver injury induced by alcohol. Phytother. Res. 2012, 26, 1857-1863. [CrossRef] [PubMed]

70. Al-Rubaei, Z.M.; Mohammad, T.U.; Ali, L.K. Effects of local curcumin on oxidative stress and total antioxidant capacity in vivo study. Pak. J. Biol. Sci. 2014, 17, 1237-1241. [CrossRef] [PubMed]

71. Faten, R.A.; Ibrahim, A.E.; Khaled, A.E. Protective and modulatory effects of Curcumin and L-Carnitine against Methotrexate-induced Oxidative stress in albino rats. Res. J. Pharm. Biol. Chem. Sci. 2013, 4, 744-754.

72. Hemeida, R.A.; Mohafez, O.M. Curcumin attenuates methotraxate-induced hepatic oxidative damage in rats. J. Egypt. Natl. Cancer Inst. 2008, 20, 141-148.

73. AL-Harbi, S.M.; Hamza, Z.R.; Dwary, A.A. Ameliorative effect of selenium and curcumin on sodium fluoride induced hepatotoxicity and oxidative stress in male mice. J. Chem. Pharm. Res. 2014, 6, 984-998.

74. Alp, H.; Aytekin, I.; Hatipoglu, N.K.; Alp, A.; Ogun, M. Effects of sulforophane and curcumin on oxidative stress created by acute malathion toxicity in rats. Eur. Rev. Med. Pharmacol. Sci. 2012, 16, 144-148. [PubMed]

75. Hussein, A.S.; El-Said Azab, M.; El-Shall, K.S. Protective effect of curcumin on antioxidant defense system and oxidative stress in liver tissue of iron overloading rats. Asian J. Clin. Nutr. 2014, 6, 1-17. [CrossRef] 
76. Eybl, V.; Kotyzova, D.; Koutensky, J. Comparative study of natural antioxidants-curcumin, resveratrol and melatonin-in cadmium-induced oxidative damage in mice. Toxicology 2006, 225, 150-156. [CrossRef] [PubMed]

77. Ciftci, O.; Ozdemir, I.; Tanyildizi, S.; Yildiz, S.; Oguzturk, H. Antioxidative effects of curcumin, $\beta$-myrcene and 1, 8-cineole against 2, 3, 7,8-tetrachlorodibenzo-p-dioxin-induced oxidative stress in rats liver. Toxicol. Ind. Health 2011, 27, 447-453. [CrossRef] [PubMed]

78. Coneac, A.; Meda, S.O.; Leucuta, D.C.; Decea, N.; Filip, M.; Mihu, C.M.; Muresan, A.; Remus, I.O.; Moldovan, M. Effect of Curcumin on Oxidative Stress in a Model of Turpentine Induced Acute Experimental Inflammation. Not. Bot. Horti Agrobot. Cluj-Napoca 2017, 45. [CrossRef]

79. Dai, C.; Tang, S.; Li, D.; Zhao, K.; Xiao, X. Curcumin attenuates quinocetone-induced oxidative stress and genotoxicity in human hepatocyte L02 cells. Toxicol. Mech. Methods 2015, 25, 340-346. [CrossRef] [PubMed]

80. Liu, Z.; Dou, W.; Zheng, Y.; Wen, Q.; Qin, M.; Wang, X.; Tang, H.; Zhang, R.; Lv, D.; Wang, J.; et al. Curcumin upregulates Nrf2 nuclear translocation and protects rat hepatic stellate cells against oxidative stress. Mol. Med. Rep. 2016, 13, 1717-1724. [CrossRef] [PubMed]

81. Eybl, V.; Kotyzová, D.; Bludovská, M. The effect of curcumin on cadmium-induced oxidative damage and trace elements level in the liver of rats and mice. Toxicol. Lett. 2004, 151, 79-85. [CrossRef] [PubMed]

82. Samarghandian, S.; Azimi-Nezhad, M.; Farkhondeh, T.; Samini, F. Anti-oxidative effects of curcumin on immobilization-induced oxidative stress in rat brain, liver and kidney. Biomed. Pharmacother. 2017, 87, 223-229. [CrossRef] [PubMed]

83. Fu, Y.; Zheng, S.; Lin, J.; Ryerse, J.; Chen, A. Curcumin protects the rat liver from CCl4-caused injury and fibrogenesis by attenuating oxidative stress and suppressing inflammation. Mol. Pharmacol. 2008, 73, 399-409. [CrossRef] [PubMed]

84. Reyes-Gordillo, K.; Segovia, J.; Shibayama, M.; Vergara, P.; Moreno, M.G.; Muriel, P. Curcumin protects against acute liver damage in the rat by inhibiting NF- $\mathrm{kB}$, proinflammatory cytokines production and oxidative stress. Biochim. Biophys. Acta 2007, 1770, 989-996. [CrossRef] [PubMed]

85. Singh, R.; Sharma, P. Hepatoprotective effect of curcumin on lindane-induced oxidative stress in male wistar rats. Toxicol. Int. 2011, 18, 124. [PubMed]

86. Sankar, P.; Telang, A.G.; Manimaran, A. Protective effect of curcumin on cypermethrin-induced oxidative stress in Wistar rats. Exp. Toxicol. Pathol. 2012, 64, 487-493. [CrossRef] [PubMed]

87. Watanabe, S.; Fukui, T. Suppressive effect of curcumin on trichloroethylene-induced oxidative stress. J. Nutr. Sci. Vitaminol. 2000, 46, 230-234. [CrossRef] [PubMed]

88. Cerný, D.; Lekić, N.; Váňová, K.; Muchová, L.; Hořínek, A.; Kmoníčková, E.; Zídek, Z.; Kameníková, L.; Farghali, H. Hepatoprotective effect of curcumin in lipopolysaccharide/-galactosamine model of liver injury in rats: Relationship to HO-1/CO antioxidant system. Fitoterapia 2011, 82, 786-791. [CrossRef] [PubMed]

89. Chen, H.; Xue, C.G.; Chen, T.H.; Wang, J.L.; Sun, C.S. Chemopreventive effect of curcuma and curcumin on liver injury induced by microcystins in mice. Chin. Pharmacol. Bull. 2005, 21, 1517-1519.

90. Tokaç, M.; Taner, G.; Aydın, S.; Ozkardeş, A.B.; Dündar, H.Z.; Taşlıpınar, M.Y.; Arıkök, A.T.; Kılıç, M.; Başaran, A.A.; Basaran, N. Protective effects of curcumin against oxidative stress parameters and DNA damage in the livers and kidneys of rats with biliary obstruction. Food Chem. Toxicol. 2013, 61, 28-35. [CrossRef] [PubMed]

91. Ghoreshi, Z.A.; Kabirifar, R.; Safari, F.; Karimollah, A.; Moradi, A.; Eskandari-Nasab, E. Hepatoprotective effects of curcumin in rats after bile duct ligation via downregulation of Rac1 and NOX1. Nutrition 2017, 36, 72-78. [CrossRef] [PubMed]

92. Lin, C.M.; Lee, J.F.; Chiang, L.L.; Chen, C.F.; Wang, D.; Su, C.L. The protective effect of curcumin on ischemia-reperfusion-induced liver injury. In Transplantation Proceedings; Elsevier: Amsterdam, The Netherlands, 2012; Volume 44, pp. 974-977.

93. Jayakumara, T.; Sakthivel, M.; Thomasb, P.A.; Geraldinea, P. Pleurotus ostreatus, an oyster mushroom, decreases the oxidative stress induced by carbon tetrachloride in rat kidneys, heart and brain. Chem.-Biol. Interact. 2008, 176, 108-120. [CrossRef] [PubMed]

94. Fadda, L.M.; Al-Rasheed, N.M.; Hasan, I.H.; Ali, H.M.; Al-Rasheed, N.M.; Al-Fayez, M.; Ahmed, A.M.; Almutlaq, N.; Qasem, N.; Reem Khalaf, R. Bax and CD68 expression in response to liver injury induced by acetaminophen: The hepatoprotective role of thymoquinone and curcumin. Pak. J. Zool. 2017, 49, 85-93. [CrossRef] 
95. Galaly, S.R.; Ahmed, O.M.; Mahmoud, A.M. Thymoquinone and curcumin prevent gentamicin-induced liver injury by attenuating oxidative stress, inflammation and apoptosis. J. Physiol. Pharmacol. 2014, 65, 823-832. [PubMed]

96. El-Agamy, D.S. Comparative effects of curcumin and resveratrol on aflatoxin B 1-induced liver injury in rats. Arch. Toxicol. 2010, 84, 389-396. [CrossRef] [PubMed]

97. Madkour, N.K. Protective effect of curcumin on oxidative stress and DNA fragmentation against lambda cyhalothrin-induced liver damage in rats. J. Appl. Pharm. Sci. 2012, 2, 76-81.

98. Lee, H.Y.; Kim, S.W.; Lee, G.H.; Choi, M.K.; Jung, H.W.; Kim, Y.J.; Kwon, H.J.; Chae, H.J. Turmeric extract and its active compound, curcumin, protect against chronic CCl4-induced liver damage by enhancing antioxidation. BMC Complement. Altern. Med. 2016, 16, 316. [CrossRef] [PubMed]

99. Park, E.J.; Jeon, C.H.; Ko, G.; Kim, J.; Sohn, D.H. Protective effect of curcumin in rat liver injury induced by carbon tetrachloride. J. Pharm. Pharmacol. 2000, 52, 437-440. [CrossRef] [PubMed]

100. Liu, W.; Xu, Z.; Li, H.; Guo, M.; Yang, T.; Feng, S.; Xu, B.; Deng, Y. Protective effects of curcumin against mercury-induced hepatic injuries in rats, involvement of oxidative stress antagonism, and Nrf2-ARE pathway activation. Hum. Exp. Toxicol. 2017, 36, 949-966. [CrossRef] [PubMed]

101. García-Niño, W.R.; Pedraza-Chaverrí, J. Protective effect of curcumin against heavy metals-induced liver damage. Food Chem. Toxicol. 2014, 69, 182-201. [CrossRef] [PubMed]

102. Cao, L.; Ding, W.; Du, J.; Jia, R.; Liu, Y.; Zhao, C.; Shen, Y.; Yin, G. Effects of curcumin on antioxidative activities and cytokine production in Jian carp (Cyprinus carpio var. Jian) with CCl4-induced liver damage. Fish Shellfish Immunol. 2015, 43, 150-157. [CrossRef] [PubMed]

103. Mortezaee, K.; Khanlarkhani, N. Melatonin application in targeting oxidative-induced liver injuries: A review. J. Cell. Physiol. 2017, 233, 4015-4032. [CrossRef] [PubMed]

104. Vera-Ramirez, L.; Pérez-Lopez, P.; Varela-Lopez, A.; Ramirez-Tortosa, M.; Battino, M.; Quiles, J.L. Curcumin and liver disease. Biofactors 2013, 39, 88-100. [CrossRef] [PubMed]

105. Sayed, M.M.; El-Kordy, E.A. The protective effect of curcumin on paracetamol-induced liver damage in adult male rabbits: Biochemical and histological studies. Egypt. J. Histol. 2014, 37, 629-639. [CrossRef]

106. Dattani, J.J.; Rajput, D.K.; Moid, N.; Highland, H.N.; George, L.B.; Desai, K.R. Ameliorative effect of curcumin on hepatotoxicity induced by chloroquine phosphate. Environ. Toxicol. Pharmacol. 2010, 30, 103-109. [CrossRef] [PubMed]

107. Otuechere, C.A.; Abarikwu, S.O.; Olateju, V.I.; Animashaun, A.L.; Kale, O.E. Protective effect of curcumin against the liver toxicity caused by propanil in rats. Int. Sch. Res. Notices 2014, 2014. [CrossRef] [PubMed]

108. Fazal, Y.; Fatima, S.N.; Shahid, S.M.; Mahboob, T. Effects of curcumin on angiotensin-converting enzyme gene expression, oxidative stress and anti-oxidant status in thioacetamide-induced hepatotoxicity. J. Renin-Angiotensin-Aldosterone Syst. 2015, 16, 1046-1051. [CrossRef] [PubMed]

109. Shapiro, H.; Ashkenazi, M.; Weizman, N.; Shahmurov, M.; Aeed, H.; Bruck, R. Curcumin ameliorates acute thioacetamide-induced hepatotoxicity. J. Gastroenterol. Hepatol. 2006, 21, 358-366. [CrossRef] [PubMed]

110. Kaur, G.; Tirkey, N.; Bharrhan, S.; Chanana, V.; Rishi, P.; Chopra, K. Inhibition of oxidative stress and cytokine activity by curcumin in amelioration of endotoxin-induced experimental hepatoxicity in rodents. Am. J. Clin. Exp. Immunol. 2006, 145, 313-321. [CrossRef] [PubMed]

111. Khorsandi, L.; Mansouri, E.; Orazizadeh, M.; Jozi, Z. Curcumin Attenuates Hepatotoxicity Induced by Zinc Oxide Nanoparticles in Rats. Balk. Med. J. 2016, 33, 252. [CrossRef] [PubMed]

112. Moghaddam, A.H.; Nabavi, S.F.; Nabavi, S.M.; Loizzo, M.R.; Roohbakhsh, A.; Setzer, W.N. Ameliorative effects of curcumin against sodium fluoride-induced hepatotoxicity. Prog. Nutr. 2015, 17, 324-330.

113. El-Desoky, G.E.; Abdel-Ghaffar, A.; Al-Othman, Z.A.; Habila, M.A.; Al-Sheikh, Y.A.; Ghneim, H.K.; Giesy, J.P.; Aboul-Soud, M.A. Curcumin protects against tartrazine-mediated oxidative stress and hepatotoxicity in male rats. Eur. Rev. Med. Pharmacol. Sci. 2017, 21, 635-645. [PubMed]

114. García-Niño, W.R.; Tapia, E.; Zazueta, C.; Zatarain-Barrón, Z.L.; Hernández-Pando, R.; Vega-García, C.C.; Pedraza-Chaverrí, J. Curcumin pretreatment prevents potassium dichromate-induced hepatotoxicity, oxidative stress, decreased respiratory complex I activity, and membrane permeability transition pore opening. Evid.-Based Complement. Altern. Med. 2013, 2013. [CrossRef] [PubMed] 
115. García-Niño, W.R.; Zatarain-Barrón, Z.L.; Hernández-Pando, R.; Vega-García, C.C.; Tapia, E.; Pedraza-Chaverri, J. Oxidative stress markers and histological analysis in diverse organs from rats treated with a hepatotoxic dose of Cr (VI): Effect of curcumin. Biol. Trace Elem. Res. 2015, 167, 130-145. [CrossRef] [PubMed]

116. Bruck, R.; Ashkenazi, M.; Weiss, S.; Goldiner, I.; Shapiro, H.; Aeed, H.; Genina, O.; Helpern, Z.; Pines, M. Prevention of liver cirrhosis in rats by curcumin. Liver Int. 2007, 27, 373-383. [CrossRef] [PubMed]

117. Reyes-Gordillo, K.; Segovia, J.; Shibayama, M.; Tsutsumi, V.; Vergara, P.; Moreno, M.G.; Muriel, P. Curcumin prevents and reverses cirrhosis induced by bile duct obstruction or CCl4 in rats: Role of TGF- $\beta$ modulation and oxidative stress. Fundam. Clin. Pharmacol. 2008, 22, 417-427. [CrossRef] [PubMed]

118. Chenari, S.; Safari, F.; Moradi, A. Curcumin enhances liver SIRT3 expression in the rat model of cirrhosis. Iran. J. Basic Med. Sci. 2017, 20, 1306. [PubMed]

119. Akila, G.; Rajakrishnan, V.; Viswanathan, P.; Rajashekaran, K.N.; Menon, V.P. Effects of curcumin on lipid profile and lipid peroxidation status in experimental hepatic fibrosis. Hepatol. Res. 1998, 11, 147-157. [CrossRef]

120. Erenoğlu, C.; Kanter, M.; Aksu, B.; Sağıroğlu, T.; Ayvaz, S.; Aktaş, C.; Erboğa, M. Protective effect of curcumin on liver damage induced by biliary obstruction in rats. Balk. Med. J. 2011, 28, 352-357. [CrossRef]

121. Zhong, W.; Qian, K.; Xiong, J.; Ma, K.; Wang, A.; Zou, Y. Curcumin alleviates lipopolysaccharide induced sepsis and liver failure by suppression of oxidative stress-related inflammation via PI3K/AKT and NF-kB related signaling. Biomed. Pharmacother. 2016, 83, 302-313. [CrossRef] [PubMed]

122. Lee, J.H.; Friso, S.; Choi, S.W. Epigenetic mechanisms underlying the link between non-alcoholic fatty liver diseases and nutrition. Nutrients 2014, 6, 3303-3325. [CrossRef] [PubMed]

123. Podrini, C.; Borghesan, M.; Greco, A.; Pazienza, V.; Mazzoccoli, G.; Vinciguerra, M. Redox homeostasis and epigenetics in non-alcoholic fatty liver disease (NAFLD). Curr. Pharm. Des. 2013, 19, 2737-2746. [CrossRef] [PubMed]

124. Tsuchida, T.; Friedman, S.L. Mechanisms of hepatic stellate cell activation. Nat. Rev. Gastroenterol. Hepatol. 2017, 14, 397.

125. de Mello, V.D.; Matte, A.; Perfilyev, A.; Männistö, V.; Rönn, T.; Nilsson, E.; Käkelä, P.; Ling, C.; Pihlajamäki, J. Human liver epigenetic alterations in non-alcoholic steatohepatitis are related to insulin action. Epigenetics 2017, 12, 287-295. [CrossRef] [PubMed]

126. Moreno, F.S.; Heidor, R.; Pogribny, I.P. Nutritional epigenetics and the prevention of hepatocellular carcinoma with bioactive food constituents. Nutr. Cancer 2016, 68, 719-733. [CrossRef] [PubMed]

127. Momtazi, A.A.; Derosa, G.; Maffioli, P.; Banach, M.; Sahebkar, A. Role of microRNAs in the therapeutic effects of curcumin in non-cancer diseases. Mol. Diagn. Ther. 2016, 20, 335-345. [CrossRef] [PubMed]

128. Zheng, J.; Wu, C.; Lin, Z.; Guo, Y.; Shi, L.; Dong, P.; Lu, Z.; Gao, S.; Liao, Y.; Chen, B.; Yu, F. Curcumin up-regulates phosphatase and tensin homologue deleted on chromosome 10 through microRNA-mediated control of DNA methylation-A novel mechanism suppressing liver fibrosis. FEBS J. 2014, 281, 88-103. [CrossRef] [PubMed]

129. Liu, Y.; Zhou, J.; Hu, Y.; Wang, J.; Yuan, C. Curcumin inhibits growth of human breast cancer cells through demethylation of DLC1 promoter. Mol. Cell. Biochem. 2017, 425, 47-58. [CrossRef] [PubMed]

130. Li, Y.Y.; Tang, D.; Du, Y.L.; Cao, C.Y.; Nie, Y.Q.; Cao, J.; Zhou, Y.J. Fatty liver mediated by PPAR- $\alpha$ DNA methylation can be reversed by a methylation inhibitor and curcumin. J. Dig. Dis. 2018. [CrossRef] [PubMed]

131. Holder, G.M.; Plummer, J.L.; Ryan, A.J. The metabolism and excretion of curcumin (1, 7-bis-(4-hydroxy-3-methoxyphenyl)-1, 6-heptadiene-3, 5-dione) in the rat. Xenobiotica 1978, 8, 761-768. [CrossRef] [PubMed]

132. Ravindranath, V.; Chandrasekhara, N. Metabolism of curcumn-studies with [3H] curcumin. Toxicology 1981, 22, 337-344. [CrossRef]

133. Pan, M.-H.; Huang, -T.; Lin, -J. Biotransformation of curcumin through reduction and glucuronidation in mice. Drug Metab. Dispos. 1999, 27, 486-494. [PubMed] 
134. Marczylo, T.H.; Verschoyle, R.D.; Cooke, D.N.; Morazzoni, P.; Steward, W.P.; Gescher, A.J. Comparison of systemic availability of curcumin with that of curcumin formulated with phosphatidylcholine. Cancer Chemother. Pharmacol. 2007, 60, 171-177. [CrossRef] [PubMed]

135. Algandaby, M.M.; Al-Sawahli, M.M.; Ahmed, O.A.; Fahmy, U.A.; Abdallah, H.M.; Hattori, M.; Ashour, O.M.; Abdel-Naim, A.B. Curcumin-Zein Nanospheres Improve Liver Targeting and Antifibrotic Activity of Curcumin in Carbon Tetrachloride-Induced Mice Liver Fibrosis. J. Biomed. Nanotechnol. 2016, 12, 1746-1757. [CrossRef] [PubMed]

136. Liu, X.; Sun, Q.; Wang, H.; Zhang, L.; Wang, -J. Microspheres of corn protein, zein, for an ivermectin drug delivery system. Biomaterials 2005, 26, 109-115. [CrossRef] [PubMed]

137. Lai, L.; Guo, H. Preparation of new 5-fluorouracil-loaded zein nanoparticles for liver targeting. Int. J. Pharm. 2011, 404, 317-323. [CrossRef] [PubMed]

138. Ahmad, M.; Taweel, G.M.A.; Hidayathulla, S. Nano-composites chitosan-curcumin synergistically inhibits the oxidative stress induced by toxic metal cadmium. Int. J. Biol. Macromol. 2018, 108, 591-597. [CrossRef] [PubMed]

139. Singh, N.; Khullar, N.; Kakkar, V.; Kaur, I.P. Attenuation of carbon tetrachloride-induced hepatic injury with curcumin-loaded solid lipid nanoparticles. BioDrugs 2014, 28, 297-312. [CrossRef] [PubMed]

140. Um, M.Y.; Hwang, K.H.; Ahn, J.; Ha, T.Y. Curcumin Attenuates Diet-Induced Hepatic Steatosis by Activating AMP-Activated Protein Kinase. Basic Clin. Pharmacol. Toxicol. 2013, 113, 152-157. [CrossRef] [PubMed]

141. Wang, Y.; Li, J.; Zhuge, L.; Su, D.; Yang, M.; Tao, S.; Li, J. Comparison between the efficacies of curcumin and puerarin in C57BL/ 6 mice with steatohepatitis induced by a methionine-and choline-deficient diet. Exp. Ther. Med. 2014, 7, 663-668. [CrossRef] [PubMed]

142. Ireson, C.; Orr, S.; Jones, D.J.; Verschoyle, R.; Lim, C.-K.; Luo, J.-L.; Howells, L.; Plummer, S.; Jukes, R.; Williams, M. Characterization of metabolites of the chemopreventive agent curcumin in human and rat hepatocytes and in the rat in vivo, and evaluation of their ability to inhibit phorbol ester-induced prostaglandin E2 production. Cancer Res. 2011, 61, 1058-1064.

143. Rahmani, S.; Asgary, S.; Askari, G.; Keshvari, M.; Hatamipour, M.; Feizi, A.; Sahebkar, A. Treatment of Non-alcoholic Fatty Liver Disease with Curcumin: A Randomized Placebo-controlled Trial. Phytother. Res. 2016, 30, 1540-1548. [CrossRef] [PubMed]

144. Panahi, Y.; Kianpour, P.; Mohtashami, R.; Jafari, R.; Simental-Mendía, L.E.; Sahebkar, A. Efficacy and Safety of Phytosomal Curcumin in Non-Alcoholic Fatty Liver Disease: A Randomized Controlled Trial. Drug Res. 2017, 67, 244-251. [CrossRef] [PubMed]

145. Cabezas, J.; Mayorga, M.; Crespo, J. Nonalcoholic Fatty Liver Disease: A Pathological View. In Liver Biopsy-Indications, Procedures, Results; InTech: Rijeka, Croatia, 2012; Chapter 8.

146. Huang, Y.; Cao, S.; Zhang, Q.; Zhang, H.; Fan, Y.; Qiu, F.; Kang, N. Biological and pharmacological effects of hexahydrocurcumin, a metabolite of curcumin. Arch. Biochem. Biophys. 2018, 646, 31-37. [CrossRef] [PubMed]

147. Wang, J.; Yu, X.; Zhang, L.; Wang, L.; Peng, Z.; Chen, Y. The pharmacokinetics and tissue distribution of curcumin and its metabolites in mice. Biomed. Chromatogr. 2018, e4267. [CrossRef] [PubMed]

148. Motterlini, R.; Foresti, R.; Bassi, R.; Green, C.J. Curcumin, an antioxidant and anti-inflammatory agent, induces heme oxygenase- 1 and protects endothelial cells against oxidative stress. Free Radic. Biol. Med. 2000, 28, 1303-1312. [CrossRef]

149. Vitek, L.; Schwertner, H.A. The heme catabolic pathway and its protective effects on oxidative stress-mediated diseases. Adv. Clin. Chem. 2007, 43, 1-57. [PubMed]

150. Zheng, S.; Anping, C.H. Activation of PPAR $\gamma$ is required for curcumin to induce apoptosis and to inhibit the expression of extracellular matrix genes in hepatic stellate cells in vitro. Biochem. J. 2004, 384, 149-157. [CrossRef] [PubMed]

151. Zheng, S.; Chen, A. Curcumin suppresses the expression of extracellular matrix genes in activated hepatic stellate cells by inhibiting gene expression of connective tissue growth factor. Am. J. Physiol. Gastrointest. Liver Physiol. 2006, 290, G883-G893. [CrossRef] [PubMed] 
152. Zheng, S.; Yumei, F.; Chen, A. De novo synthesis of glutathione is a prerequisite for curcumin to inhibit hepatic stellate cell (HSC) activation. Free Radic. Biol. Med. 2007, 43, 444-453. [CrossRef] [PubMed]

153. Gukovsky, I.; Reyes, C.N.; Vaquero, E.C.; Gukovskaya, A.S.; Pandol, S.J. Curcumin ameliorates ethanol and nonethanol experimental pancreatitis. Am. J. Physiol. Gastrointest. Liver Physiol. 2003, 284, G85-G95. [CrossRef] [PubMed]

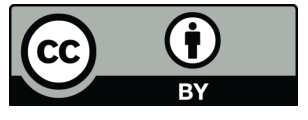

(c) 2018 by the authors. Licensee MDPI, Basel, Switzerland. This article is an open access article distributed under the terms and conditions of the Creative Commons Attribution (CC BY) license (http:/ / creativecommons.org/licenses/by/4.0/). 